\title{
Hoofstuk 10
}

\section{Die teks van die Nuwe Testament}

In hierdie laaste hoofstuk word die praktyk van die Nuwe-Testamentiese Tekskritiek aan die orde gestel. Sommige van die variasie-eenhede in die Griekse Nuwe Testament uit die apparaat van UBS 3a, wat 'n invloed op die twee Afrikaanse vertalings het, word bespreek. Dit sluit alle probleme wat in die Nuwe Afrikaanse vertaling van tekskritiese voetnote voorsien is, in. Uit die aard van die saak kan geen volledige bespreking gebied word nie, maar word die belangrikste aspekte van die probleem bloot in 'n kort paragraaf afgehandel.

\section{DIE NUWE TESTAMENT IN DIE ALGEMEEN}

Onder die belangrikste teksuitgawes van die Griekse Nuwe Testament is NA ${ }^{26}$ en UBS3a, die Greek-English Diglot van Kilpatrick en die GNTMT. Vir hulle kritiese apparate is ook nog Tischendorf 8 en die teks van Von Soden belangrik, omdat dit die enigste volledige tekste van die Griekse Nuwe Testament is wat 'n volledige kritiese apparaat bevat. Daarnaas is die Textual Commentary van Bruce Metzger (1971) vermeldenswaardig. Daarin word 'n uiteensetting van die redes vir die keuse van lesings in die UBS-tekste gegee. Dit is, met die uitsondering van die bespreking van variasie-eenhede deur Wetscott en Hort in die bylaag by hul teks, die enigste tekskritiese kommentaar oor die Nuwe Testament en is vandag 'n belangrike bron van inligting oor die teks.

Literatuur. Metzger 1971.

\section{DIE EVANGELIES}

Uit 'n praktiese oogpunt beskou, is die teks van die Evangelies verreweg die belangrikste deel van die Nuwe Testament sover dit die Nuwe-Testamentiese Tekskritiek aangaan. Verreweg die meeste aandag is aan hierdie deel van die Nuwe Testament gegee, en die meeste teorieë oor veral die geskiedenis van die teks berus op navorsing ten opsigte van die teks van die Evangelies. Die rede daarvoor is onder andere dat die meerderheid manuskripte wat gevind is, die Evangelies bevat.

Literatuur: Fischer 1987; Kilpatrick 1943; 1967a; 1971; 1977a; Klijn 1959a; 1959b; 1969; Lake 1902; Lindbars 1957/58; Metzger 1945; Saunders 1952; MA Smith 1968; Streeter 1924; 1937; Suggs 1957; Wallace-Hadrill 1956. 


\subsection{Die Sinoptiese Evangelies}

Onder die Evangelies neem die Sinoptiese Evangelies ook in die Tekskritiek'n besondere plek in vanweë hulle onderlinge verband, veral omdat hulle vir 'n besondere soort tekskritiese probleem verantwoordelik was. Die feit dat die bewoording van die eerste drie Evangelies in baie gevalle baie naby mekaar is, het daartoe gelei dat hul tekste dikwels deur skriptors geharmonieer is. Die Diatessaron het veel tot hierdie probleem bygedra en was waarskynlik die bron van baie harmoniërings. Die Sinoptiese Evangelies is die een gedeelte van die Nuwe Testament waar die onderskeid tussen Tekskritiek en Historiese of Literêre Kritiek gevolglik baie klein is.

Onder die teksuitgawes van die Griekse Nuwe Testament neem die Sinopsisse van die Evangelies 'n besondere plek in. Hierin word die teks van die vier Evangelies (in sommige gevalle net die drie Sinoptiese Evangelies) in vertikale kolomme langs mekaar gegee, sodat die teks van dié gedeeltes wat in meer as een Evangelie voorkom, maklik met mekaar vergelyk kan word. In die kritiese apparaat van hierdie tekste word gewoonlik baie aandag aan die verskynsel van harmoniërings gegee. Sedert die sewentigerjare het 'n hele aantal van dié Sinopsisse verskyn. Die belangrikstes is dié van Aland, wat op die teks van NA ${ }^{26}$ gebaseer is, en dié van Greeven en Orchard.

Literatuur: K Aland (ed) 1978; Baarda 1969; Burrows 1976; Delobel 1982; JK Elliott 1980b; 1986a; Fee 1978c; 1980c; Greeven 1959/60; Greeven (ed) 1981; Neirynck \& Van Segbroeck 1982; Orchard (ed) 1983; Wikgren 1951.

\subsection{Matteus}

Die Eerste Evangelie is verreweg die meeste in die vroeë kerk gelees en gebruik. Om hierdie rede was die Matteusevangelie dikwels die bron van harmoniering in die ander Evangelies.

Onder merkwaardige gepubliseerde tekste van Matteus tel die uitgawe van Legg, waarin 'n volledige kritiese apparaat vir die Matteusevangelie vervat is, en die uitgawes van die Vetus Latina deur Jülicher, Matzkow en Aland, wat die lesings van die oud-Latynse manuskripte bevat. Die oudste bronne van die Matteusevangelie is die volgende:

2de eeu: $P^{77}$ Diat; 3de eeu: $P^{1,37,45,53,64,67,70} 0212$ sa; 4de eeu: $P^{19,21,25,35,62,86,88 ~} \times$ B W 0580160017102310242 a k syc,s bo mf goth. 
Literatuur: E Bammel 1961; 1973; DA Black 1988; Champlin 1964; Crouzel 1972/73; Fischer 1987 1988; Geerlings 1961b; Globe 1980; Hirunuma 1981; Holmes 1984; 1986; Jülicher, Matzkow \& Aland (ed) 1972; Kilpatrick 1944a; 1947b; 1979b; KW Kim 1949; Klijn 1981; Legg (ed) 1940; Metzger 1972a; O'Callaghan 1981; 1988; Schwank 1962; Smit Sibinga 1966; 1981; Suggs 1956; Williams 1942.

\section{(a) Mt 6: 13}

Onder die variasie in die bronne van die Eerste Evangelie is min waarskynlik so interessant soos die slot van die Ons Vader, Mt 6: 13. In die OAB lui hierdie vers soos volg: 'en lei ons nie in versoeking nie, maar verlos ons van die Bose. Want aan $\mathrm{U}$ behoort die koninkryk en die krag en die heerlikheid tot in ewigheid, Amen'. In die NAB ontbreek die laaste gedeelte en die vers lui soos volg: 'en laat ons nie in versoeking kom nie maar verlos ons van die Bose'. Wanneer na die tekskritiese apparaat van hierdie gedeelte geblaai word, word dit duidelik dat daar in werklikheid 'n hele aantal variante lesings voorkom

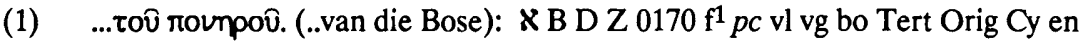
enkele kerkvaders

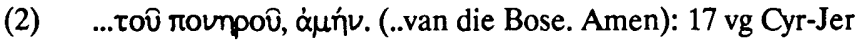

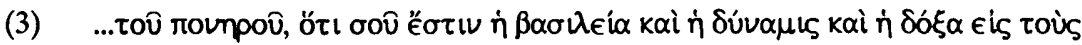

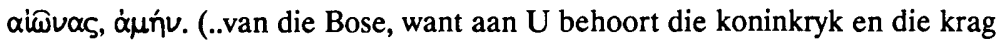
en die heerlikheid tot in ewigheid. Amen): K L W $\Delta \Theta$ II f13 2833565700 89210711241 Byz Lect f q syh,pal bo goth arm geo Diat Chry

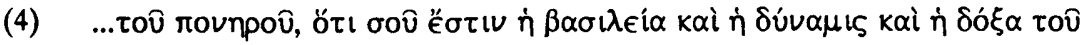

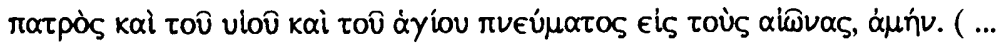
van die Bose, want aan $U$ behoort die koninkryk en die krag en die heerlikheid, van die Vader en die Seun en die Heilige Gees tot in ewigheid. Amen): 157225418

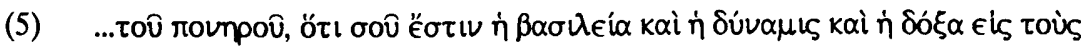

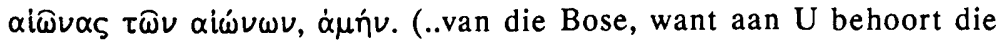
koninkryk en die krag en die heerlikheid tot in die ewigheid van die ewigheid. Amen): 2148

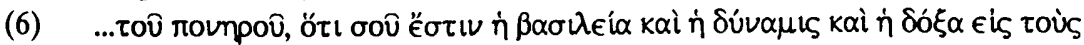
aiwuac. (..van die Bose, want aan U behoort die koninkryk en die krag en die heerlikheid tot in ewigheid): $\mathrm{g}^{1}$ syp

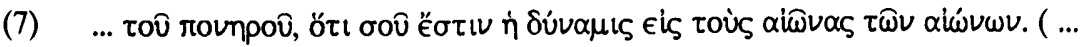
van die Bose, want aan $U$ behoort die krag tot in die ewigheid van die ewigheid): $k$ 


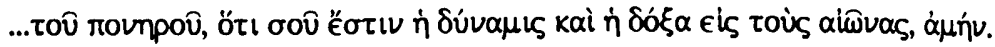
(..van die Bose, want aan $\mathrm{U}$ behoort die krag en die heerlikheid tot in ewigheid. Amen): sa $\mathrm{mf}$

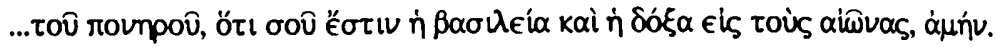
(..van die Bose, want aan $U$ behoort die koninkryk en die heerlikheid tot in ewigheid. Amen): syc

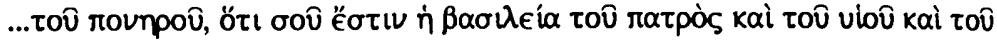

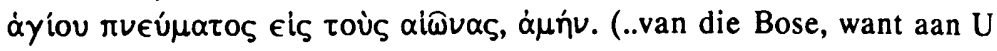
behoort die koninkryk van die Vader en die Seun en die Heilige Gees tot in ewigheid. Amen): 1253

Die slot van die 'Ons Vader' is dus in tien verskillende vorme in die manuskripte oorgelewer, waarvan nege met mekaar verband hou. Wanneer na die eksterne getuienis gekyk word, kan 'n aantal van hierdie lesings vroeg in die beoordelingsproses reeds uitgeskakel word. Die feit dat lesings 6, 7, 8 en 9 slegs in manuskripte van vertalings voorkom, maak dit twyfelagtig of hierdie lesings enige werklike aanspraak op verteenwoordiging van die oorspronklike het, omdat hulle waarskynlik ontstaan het deurdat die vertaler die bewoording van die grondteks by die bekende liturgiese gebed van sy tyd en omgewing aangepas het. Lesings 4, 5 en 10 kan ewe-eens buite rekening gelaat word, omdat hulle in slegs enkele laatMiddeleeuse minuskels voorkom. Dieselfde geld lesing 2, wat in slegs enkele bronne voorkom. Dit laat dus lesings 1 en 3, die kort lesing (van die NAB) en die tradisioneel bekende lesing (van die $\mathrm{OAB}$ ). Op grond van die eksterne getuienis is dit duidelik dat die kort lesing waarskynlik die oorspronklike is. Dit kom naamlik in die oudste en beste manuskripte van Mt 6 voor ( $\mathrm{X}$ B sa) en geniet 'n vroeë wye geografiese verspreiding, deurdat dit in alle vroeë tekstipes voorkom. Lesing 3 , daarenteen, kom slegs in laat gedateerde manuskripte voor. Tog het dit steun van 'n vroeë tekstipe, deurdat dit in manuskripte van veral die Caesareaanse teks, asook enkele manuskripte van die Westerse teks, voorkom. Dit blyk dus dat die lang lesing moontlik in 'n deel van die Westerse teks ingesluit is, waarna dit na die Caesareaanse teks en uiteindelik die Bisantynse teks oorgedra is. Die kort lesing is waarskynlik die oorspronklike, was gedurende die 2 de en 3 de eeu wyd bekend, maar is sedert die 4de eeu deur die lang lesing verdring.

Die transkripsionele getuienis blyk hierdie dokumentêre geskiedenis te bevestig. Daar is oënskynlik geen rede waarom die betrokke woorde deur' $n$ skriptor weggelaat sou word indien dit in die oorspronklike teks was nie. Die enigste rede wat aangevoer kan word, is reëlweglating as gevolg van 'n sigfout. Dit oortuig egter nie, omdat verwag kan word dat hierdie gebed so bekend en gewild in die vroeë 
kerk sou wees soos vandag. Dit is dus onwaarskynlik dat (a) 'n skriptor, wat dit waarskynlik uit sy kop geken het, so 'n fout sou begaan, en (b) die fout in die lig van die algemene bekendheid van die gebed in so 'n wye gebied oorgelewer sou word. Aan die ander kant is dit makliker om die ontstaan van die lang lesing te verklaar as die kort lesing die oorspronklike was. Gebede is tradisioneel, soos vandag, met 'n gepaste frase, gewoonlik 'n doksologie (of die bekende frase 'in die naam van Jesus' vandag), afgesluit. 'n Skriptor wat die kort vorm van die gebed in die manuskrip voor hom gelees het, kon gedink het dat dit'n fout is dat die gebed sonder so 'n doksologie afgesluit is. Gevolglik het hy dit in sy manuskrip bygevoeg in 'n poging om die gebed af te rond. Die bron van die doksologie is moontlik in 1 Kron 11: 29-31 te vind. Die feit dat die lang lesing in soveel verskillende vorme voorkom (lesings 3 tot 10 ), is op sigself 'n aanduiding dat dit moontlik 'n sekondêre ontstaan gehad het, omdat dit wil voorkom of verskillende skriptors en vertalers die afsluiting van die gebed wou korrigeer deur dit by die bekende liturgiese gebede van hul tyd aan te pas.

Op grond van hierdie getuienis is die kort lesing dus as die oorspronklike in hierdie teks te kies.

Literatuur. Bandstra 1981; 1982; Van Bruggen 1982.

\section{(b) Mt 17: 20}

Nog 'n variasie-eenheid waarby 'n voetnoot in die NAB voorkom, is Mt 17: 20. Volgens die $\mathrm{OAB}$ volg vers 21 na vers 20: 'Maar hierdie geslag gaan nie uit behalwe deur gebed en vas nie'. Twee variante lesings kom in die manuskripte by hierdie teks voor:

(1) Weglating: $x^{*}$ B $\Theta 33892^{*} p c$ e ff ${ }^{1}$ syc,pal,s sa bo ${ }^{m s}$ eth geo Eus

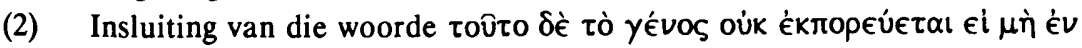

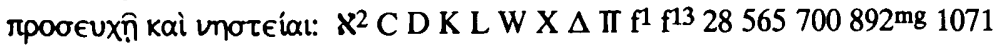
1241 Byz vl vg syp,h bo ${ }^{\text {mss }}$ arm eth geo Diat Orig Chry en enkele kerkvaders

Die weglating van die betrokke gedeelte (lesing 1) het die beste eksterne getuienis ter ondersteuning. Dit kom in die beste manuskripte voor ( $\boldsymbol{X}^{*} \mathrm{~B}$ sa) en geniet ook onder die vroegste getuienisse 'n wye geografiese verspreiding, deurdat dit in Alexandrië, Italië (of die Weste in die algemeen) en Sirië bekend was. Daarenteen is die lang lesing se getuienis beperk tot 'n goeie verspreiding in latere tye, wat almal na die insluiting van die woorde in vroeë Westerse bronne herlei kan word. 
Die lesing het waarskynlik vroeg in die Westerse teks ontstaan, waarna dit oorgedra is na ander latere teksgetuienisse van ander tekstipes, wat almal deur die Westerse teks beïnvloed is. Die transkripsionele getuienis bevestig hierdie rekonstruksie, omdat daar geen duidelike rede vir die weglating van die teks sou wees indien dit outentiek is nie, terwyl die byvoeging van die betrokke woorde verklaar kan word uit harmoniëring met $M k$ 9: 29, iets wat 'n tipiese kenmerk van die Westerse teks is. Om hierdie rede kan die gevolgtrekking dus gemaak word dat die oorspronklike teks van die Eerste Evangelie nooit ' $n$ vers 21 bevat het nie.

\section{(c) Mt 18: 10}

Mt 18: 10 is ewe-eens in die NAB van 'n tekskritiese nota voorsien. Ook hier gaan dit om die insluiting of weglating van 'n teksvers, dit wat in die OAB as vers 11 bekend gestaan het: 'Want die Seun van die Mens het gekom om te red wat verlore is':

(1) Weglating: $\times \mathrm{B} \mathrm{L}^{*} \theta \mathrm{f}^{1} \mathrm{f}^{13} 33892^{*} p c$ e $\mathrm{ff}^{1}$ sypal,s sa bo mae geo Orig Eus Hier en enkele kerkvaders

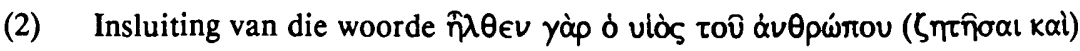

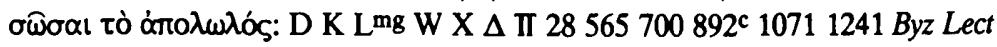
vl vg syc,p,h bomss arm geo eth Diat Chrys en enkele kerkvaders (met kleiner variasie in sommige bronne)

Lesing 1 het duidelik voorkeur bo lesing 2 op eksterne gronde, omdat dit sowel in die oudste en beste manuskripte voorkom as 'n wye geografiese verspreiding in die vroeë stadium van oorlewering geniet. Lesing 2 , daarenteen, blyk na aanleiding van die steun van veral die oud-Latynse vertalings, in die Westerse teks ontstaan het, vanwaar dit deur middel van onderlinge kontak en vermenging in ander tekstipes beland het. Hoewel daar oënskynlik geen duidelike transkripsionele rede vir die weglating of byvoeging van hierdie gedeelte is nie, is die feit dat dit woordeliks met Lk 19: 10 ooreenkom, 'n aanduiding dat dit nie in die oorspronklike teks was nie, maar eerder die gevolg van harmoniëring is. Verder is dit effens problematies in die konteks, wat die kort lesing ook op intrinsieke gronde verkieslik bo die lang lesing maak.

(d) Mt 23: 13

In Jesus se bekende uitsprake teen die Fariseërs in Mt 23, is daar twyfel oor een van 
die uitsprake, wat tradisioneel in Mt 23: 14 vertel is. In die OAB het dit soos volg gelui: 'Wee julle, skrifgeleerdes en Fariseërs, geveinsdes, want julle eet die huise van die weduwees op, en dit terwyl julle vir die skyn lang gebede doen. Daarom sal julle 'n swaarder oordeel ontvang'. Die tekskritiese apparaat by hierdie teks is soos volg:

(1) Weglating: X B D L Z $\theta$ f $33892^{*} p c$ a aur $d$ e ff $^{1} \mathrm{~g}^{1} \mathrm{vg}$ sypal(mss),s sa bomss mae arm geo Orig Eus Hier

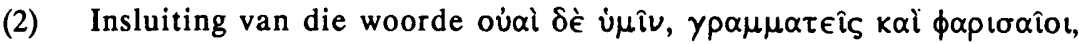
ن்

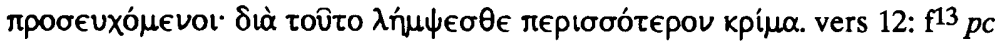
vl vg sypal(mss),c bo ${ }^{\text {mss }}$ Diat Orig Chrys

(3) Insluiting van dieselfde woorde as in lesing 2, maar na vers 13: $\mathrm{K} \mathrm{W} \Delta \Pi 28$ $565700892^{\mathrm{mg}} 10711241$ Byz Lect f syp,h bo ${ }^{\mathrm{mss}}$ eth Chrys en enkele kerkvaders

Dit is met die eerste oogopslag duidelik dat eksterne getuienis lesing 1 ondersteun. Dit kom in al die belangrike manuskripte van die Griekse Nuwe Testament, sowel as die meeste van die belangrikste vertalings voor. Daarom het dit in die 2de, 3de en 4 de eeu ook verreweg die wydste geografiese verspreiding en is dit duidelik dat dit die dominante lesing in die eerste vier eeue was. Die ander lesings word albei uit 'n datering- en geografiese oogpunt swak ondersteun in vergelyking met lesing 1 . Uit 'n transkripsionele oogpunt gesien, is die lang lesing ook 'n duidelike harmoniëring met Mk 12: 40 en Lk 20: 47, waar feitlik die identiese woorde voorkom. 'n Skriptor het die woorde waarskynlik by die teks ingesluit in 'n poging om die rede van Jesus teen die Fariseërs te voltooi, (deur 'n uitspraak wat in ander Evangelies verhaal is, maar in Matteus ontbreek het, by te voeg). Dit kom ooreen met 'n algemene tendens in die 2de eeu om uitsprake van Jesus aan te vul. Die feit dat dit op twee verskillende plekke bygevoeg is (lesing 2 en 3 ) ondersteun die outentisiteit van lesing 1 .

\section{(e) Mt 24:36}

In Mt 24: 36 kom 'n variasie-eenheid voor wat ook 'n invloed op die Afrikaanse Bybel gehad het, maar wat nie van 'n voetnoot voorsien is nie. Hierdie teks lees in die $\mathrm{OAB}$ soos volg: 'Maar van dié dag en dié uur weet niemand nie, ook die engele van die hemel nie, maar net my Vader alleen'. In die NAB lees dit soos volg: 'Maar niemand weet wanneer daardie dag en uur kom nie, nie die engele in die hemel nie en ook nie die Seun nie. Net die Vader weet dit'. Dit gaan dus om die insluiting of 
weglating van die woorde: 'ook nie die Seun nie':

(1) Weglating: $\mathrm{K}^{1} \mathrm{~K} \mathrm{~L} \mathrm{~W} \Delta \pi \mathrm{f}^{1} 3356570089210711241$ Byz Lect $\mathrm{g}^{1} \mathrm{l}$ vg sy co geo Orig Did en enkele kerkvaders

(2) Insluiting van die woorde: oúfé ò viós: $\mathrm{K}^{*}, 2 \mathrm{~B}$ D $\Theta$ f13 $^{13} 28 p c$ vl sypal $\mathrm{mf}$ arm eth geo Diat Ir Orig Chrys en enkele kerkvaders

Ten opsigte van die eksterne getuienis, kom lesing 2 met die uitsondering van die Siriese vertalings in alle vroeë geografiese gebiede voor. Dit is duidelik dat dit vroeg in sowel die Alexandrynse as Westerse tekste bekend was. Met die uitsondering van die Koptiese vertaling kom dit ook in die oudste en beste manuskripte voor. Daarenteen het lesing 1 ook getuienis van vroeë wye geografiese verspreiding. Dit kom naamlik in die Siriese en Koptiese vertalings voor, wat daarop dui dat dit wél vroeg in die Weste en in Alexandrië bekend moes gewees het. Terwyl hierdie feite eksterne getuienis ietwat balanseer, tel die feit dat lesing 2 in vroeë Griekse manuskripte voorkom tog in sy guns. Die probleem kan egter nie hiermee opgelos word nie. Op transkripsionele gronde is dit duidelik dat lesing 2 waarskynlik die beste getuienis het. Dit is duidelik dat die weglating van die woorde nie aan 'n onbewuste fout soos homoioteleuton toegeskryf kan word nie, omdat daar geen ooglopende herhalings wat dit kon veroorsaak, ter sprake is nie. Die herhaling van oúó́ (nóg...nóg) is nie hier van toepassing nie, omdat dit op die weglating van die

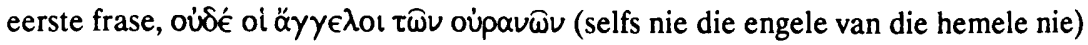
sou uitloop. 'n Tweede moontlike rede vir die sekondêre insluiting van die woorde deur skriptors kan wees dat hulle die teks met dié van Mk 13: 32, waar presies dieselfde teks voorkom, wou harmonieer. Juis die feit van die woordelikse ooreenkoms tussen die twee verse maak dit egter onwaarskynlik, omdat dit bekend is dat Matteus Markus as bron gebruik het. Waarom sou hy die vers woord-virwoord in sy Evangelie oorneem, en juis dié woorde weglaat? Wat die saak verder kompliseer, is dat daar ook in Mk 13: 32 manuskripte is wat die betrokke woorde weglaat. Die sekondêre ontstaan van die frases in beide die tekste moet dus verklaar word, indien harmoniëring 'n rol gespeel het. Die weglating van die frase deur skriptors, is aan die ander kant makliker verklaarbaar (in beide gevalle). Hierdie is waarskynlik een van die voorbeelde van verandering om leerstellige redes, wat deur ortodokse skriptors aangebring is. Die betrokke woorde is waarskynlik in manuskripte (van albei Evangelies) weggelaat om die godheid van Jesus te beskerm, sodat dit nie sou lyk of Jesus, wat kragtens sy godheid alwetend moet wees, iets nie weet nie. Op hierdie gronde moet die lang lesing in hierdie geval dus waarskynlik as verteenwoordiger van die oorspronklike teks beskou word. 


\subsection{Markus}

Die Markusevangelie is volgens alle aanduidinge die oudste van die vier Evangelies en was een van die bronne van die ander twee Sinoptiese Evangelies (Matteus en Lukas). Desnieteenstaande is dit die Evangelie wat waarskynlik die minste in die kerk gebruik is. Daar is veral twee merkwaardige aspekte van hierdie Evangelie wat vir die Nuwe-Testamentiese Tekskritiek belangrik is: (a) Dit is vandag onduidelik hoe hierdie Evangelie geeïndig het. In die bronne van die Evangelie kom drie verskillende slotgedeeltes voor. Dit is egter nie duidelik of een van hulle die oorspronklike slot was nie. (b) Vir die rekonstruksie van die teksgeskiedenis is Markus ewe-eens belangrik, omdat die bestaan van die Caesareaanse teks hoofsaaklik in die teks van die Markus geïdentifiseer is.

Onder die merkwaardige uitgawes van hierdie Evangelie is die teks van Legg, waarin ' $n$ volledige apparaat vir Markus verskaf word. Vir die oud-Latynse teks van Markus is die teks van Jülicher, Matzkow en Aland, waarin die lesings van die oudLatynse manuskripte vervat is, die enigste beskikbare teks van die Vetus Latina.

Die oudste bronne van die Markusevangelie is die volgende:

2de eeu: Diat; 3de eeu: P45 0212 sa; 4de eeu: X B W 059021501880214 a k sys,c bo mf goth.

Literatuur. Ellingworth 1979; JK Elliott 1971a; 1975a; 1981a; Fee 1980b; Fenton 1968; Geerlings 1968a; Glasson 1966; Globe 1982; Greeven 1977; Hills 1947; Hurtado 1981b; Huston 1955; Jülicher, Matzkow \& Aland (eds) 1970; Kilpatrick 1956a; 1956b; 1958a; S Lake 1937; Lake, Blake \& New 1928; Lake \& Lake; 1941; Legg (ed) 1935; JJ Miller 1986; Neirynck 1979; Omanson 1975; Osburn 1983; Rodgers 1989; Slomp 1977; Smith 1975; Smit Sibinga 1976; CH Turner 1924; 1925a; 1925b; 1925c; 1925d; 1926; 1927a; 1927b; 1927c; 1928a; 1928b; Williams 1942.

\section{(a) Mk 1:2}

In die begin van die Tweede Evangelie (Mk 1:2) kom 'n variasie-eenheid voor wat 'n invloed op die twee Afrikaanse vertalings gehad het. In die OAB word die aanhaling in vers 2 ingelui met die woorde: 'Soos geskrywe is in die Profete', terwyl die NAB die aanhaling inlui met die woorde: 'In die boek van die profeet Jesaja staan daar geskrywe'. Die variante lesings in hierdie variasie-eenheid is soos volg:

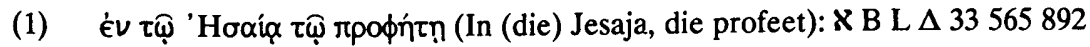
1241 (vl vg syp,pal,h(mg) co goth geo) Ir Orig

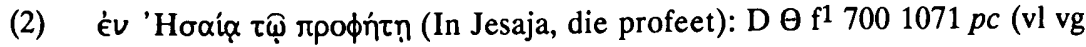


syp,pal,h(mg) co goth geo) Orig Bas enkele kerkvaders

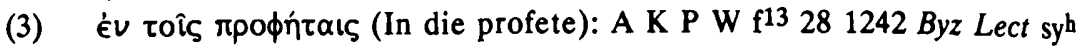
bomss(mg) arm eth Ir enkele kerkvaders

Hier lê die probleem weer tussen die lang en kort lesing, dus lesings 1 en 2 aan die een kant, en lesing 3 aan die ander kant. Die verskil tussen lesings 1 en 2 lê in die gebruik van 'n lidwoord en raak nie die essensie van die probleem nie. Die kern van die probleem is of die skrywer van die Tweede Evangelie Jesaja of die Profete as bron van die aanhaling verwys. Eksterne getuienis ondersteun lesings 1 en 2 omdat hulle in verreweg die oudste en beste manuskripte voorkom en verreweg die beste geografiese verspreiding het. Met die uitsondering van W (wat Westers in Markus 1: 1-5: 11 is), is daar geen bewys dat lesing 3 ooit buite die Bisantynse teks bekend was nie. Die feit dat dit in $\mathrm{f}^{13}$ en enkele manuskripte van die Bohairiese vertaling voorkom, is nie werklik betekenisvol nie aangesien dit maklik onder invloed van die Bisantynse teks, wat die lesing bevat, in hierdie manuskripte kan staan. Alle ander getuienis van alle ander tekstipes ondersteun lesings 1 en/of 2. Op grond hiervan moet die eksterne getuienis dus as sterk getuienis ten gunste van die eerste twee lesings geag word. (Oor die kwessie van die lidwoord is lesing 1 te kies, hoofsaaklik op grond van die feit dat $\mathrm{X}$ en $\mathrm{B}$ lesing 1 ondersteun. Hierdie gevolgtrekking word deur die transkripsionele getuienis ondersteun.) Terwyl daar geen duidelike rede is

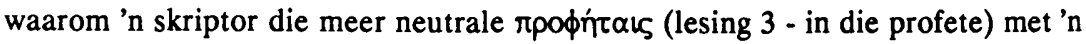
meer spesifieke verwysing na die profeet Jesaja (lesings 1 en 2) sou vervang nie, is daar ' $n$ rede waarom hy die verwysing na Jesaja met ' $n$ meer algemene verwysing sou wou vervang. Die aanhaling wat volg, kom naamlik slegs gedeeltelik uit Jesaja. Slegs die tweede gedeelte van die aanhaling ('n Stem van een wat roep..) kom uit Jesaja (40: 3), Die voorafgaande gedeelte (Kyk, Ek stuur my boodskapper..) is 'n aanhaling uit Mal 3: 1. Dit bevestig die baie sterk eksterne getuienis ten gunste van lesing 1 (en 2), omdat dit 'n duidelike poging van die skriptor was om die verwysingsfout in die Markusevangelie te korrigeer. Hierdie is dus waarskynlik ook 'n doelbewuste verandering deur ortodokse skriptors om 'n leerstellige of dogmatiese rede, naamlik om die onfeilbaarheid van die Bybel te beskerm.

\section{(b) Mk 7: 15}

By Mk 7: 15 verskyn daar 'n voetnoot in die NAB wat sê dat daar nie 'n vers 16 is nie. Die tradisionele vers 16 , 'As iemand ore het om te hoor, laat hom hoor' in die $\mathrm{OAB}$, ontbreek dus. Die kritiese apparaat is soos volg: 
(1) Weglating: $\times \mathrm{B} \mathrm{L} \Delta^{*} 28$ Lect bo ${ }^{\mathrm{mss}}$ geo

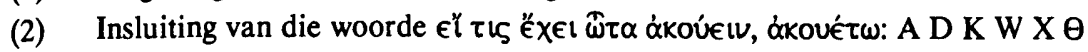
II $f^{1} \mathrm{f}^{13} 3356570089210711241 \mathrm{Byz}$ vl vg syh sa bomss goth arm eth geo Diat Aug

Eksterne getuienis ondersteun die kort lesing (lesing 1) matig, omdat die beste Griekse manuskripte ( $\mathrm{X}$ en $\mathrm{B}$ ) dit bevat. Lesing 2 het egter ' $n$ beter geografiese verspreiding as lesing 1 en kom in vroeë tekste van al die teksfamilies voor. Eksterne getuienis gee dus geen werklike uitsluitsel vir hierdie probleem nie. Ook transkripsionele getuienis gee nie uitsluitsel nie, omdat daar geen goeie redes vir die byvoeging of weglating van die teks is nie. Ook intrinsieke aspekte lewer geen duidelike riglyn op nie, ofskoon die teks effens vreemd in die konteks lyk. Op grond van die getuienis van die 'beste manuskrip' en die algemene transkripsionele reël dat die kort lesing bo die lang lesing voorkeur geniet, moet hier 'n ietwat meganiese keuse gemaak word en moet dus aanvaar word dat die lesing waarskynlik later bygevoeg is. Waarskynlik het 'n skriptor hier na aanleiding van Mk 4: 9 en 4: 23 'n nota in die kantlyn gemaak, wat deur 'n latere skriptor vir 'n korreksie aangesien is en by die teks ingesluit is. Hoe dit ookal sy, dit is 'n baie moeilike probleem om op te los, omdat geen duidelike getuienis hier na vore tree nie.

\section{(c) Mk 9:43 en 45}

In Markus se vertelling oor die struikelblokke van die lewe (Mk 9:42-50) kom by verse 43 en 45 twee interessante variasie-eenhede voor, wat in die NAB van tekskritiese notas voorsien is. Die teks van die $O A B$ lees van vers $43 b-49$ a soos volg: '(43) ..as om twee hande te hê en in die hel te gaan in die onuitbluslike vuur - (44) waar hulle wurm nie sterf en die vuur nie uitgeblus word nie. (45) En as jou voet jou laat struikel...as om twee voete te hê en in die hel gewerp te word in die onuitbluslike vuur - (46) waar hulle wurm nie sterf en die vuur nie uitgeblus word nie. (47) En as jou oog jou laat struikel...as om twee oë te hê en in die hel gewerp te word in die onuitbluslike vuur - (48) waar hulle wurm nie sterf en die vuur nie uitgeblus word nie. (49) Want elkeen sal met vuur gesout word..'. In die NAB ontbreek die twee vetgedrukte tekste. Die tekskritiese apparaat by hierdie twee verse is soos volg:

\section{Vers 43:}

(1) Weglating: $\mathrm{X} \mathrm{B} \mathrm{C} \mathrm{L} \mathrm{W} \Delta \Psi \mathrm{f}^{1} 28565892 \mathrm{k} \mathrm{sy}^{\mathrm{s}}$ sa bo mf arm geo

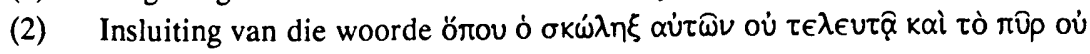




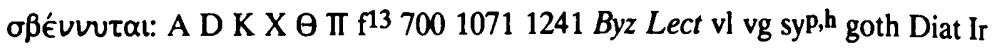
$\mathrm{Bas} \mathrm{Au}$

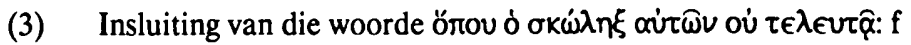

Vers 45:

(1) Weglating: $\mathrm{X} \mathrm{B} \mathrm{C} \mathrm{L} \mathrm{W} \Delta \Psi \mathrm{f}^{1} 28565892 \mathrm{k}$ sys sa bo mf arm Diat

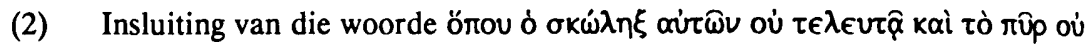

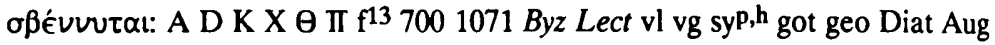
Bas

Omdat die kritiese apparaat vir albei verse byna dieselfde is, sal hulle saam bespreek word. Lesing 3 in vers 43 is waarskynlik maar die gevolg van 'n fout deur die skriptor van die oud-Latynse manuskrip f en word gevolglik nie verder oorweeg nie. In beide gevalle is die kort lesing (lesing 1) op eksterne gronde waarskynlik die oorspronklike, sowel omdat dit in die oudste en beste manuskripte voorkom, as omdat dit vroeg in getuienisse van verskillende geografiese gebiede voorkom. Dit het 'n heelwat beter vroeë verspreiding as lesing 2 , wat, op grond van veral die oudLatynse steun daarvoor, moontlik in die Westerse teks ontstaan het en vandaar na die ander getuienisse wat dit ondersteun, oorgegaan het. Uit 'n transkripsionele oogpunt gesien, is daar geen ooglopende rede waarom dit weggelaat sou word indien dit outentiek is nie. Tipies van die Westerse teks is dit waarskynlik eerder op grond van vers 48 bygevoeg in 'n poging om die driemaal herhalende waarskuwing in verse 43,45 en 47 inhoudelik af te rond, deur die 'ontbrekende' tipering van die 'hel' in vers 48 ook by die verdoemende woorde in vers 43 en 45 by te voeg.

\section{(d) Mk 11: 25}

Mk 11: 25 is ook in die NAB van 'n voetnọot voorsien, wat sê waarom daar nie 'n vers 26 in die NAB voorkom nie. Die woorde van die $\mathrm{OAB}$ wat as vers 26 bekend was, lui soos volg: 'Maar as julle nie vergewe nie, sal julle Vader wat in die hemele is, ook julle oortredinge nie vergewe nie'. Die kritiese apparaat by hierdie verse is soos volg:

(1) Weglating: K B L W $\Delta \Psi 565700892 \mathrm{k} \mathrm{l} \mathrm{vgmss} \mathrm{sys,pal} \mathrm{sa} \mathrm{bo} \mathrm{arm} \mathrm{geo}$

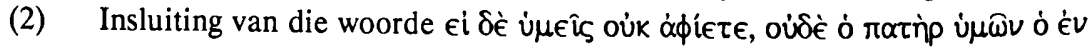

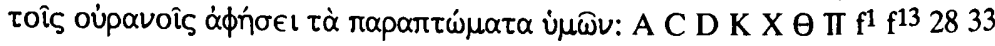
10711241 Byz Lect vl vg syrp,h bo ${ }^{\text {mss }}$ goth eth Diat Cy Aug 
Ook in hierdie variasie-eenheid het die kort lesing (lesing 1) op eksterne gronde voorkeur bo lesing 2. Dit kom in al die oudste en beste manuskripte voor, en geniet 'n vroeë wye geografiese verspreiding deurdat dit in Egipte, Sirië die Weste en Noord-Afrika bekend was. Die lang lesing het soos baie ander interpolasies aanvanklik slegs onder die Westerse teks vroeë steun, vanwaar dit deur middel van die Westerse teks se latere beïnvloeding van die ander tekstipes na daardie tekstipes oorgegaan het. Transkripsionele getuienis is in 'n sekere sin verdeel. Indien die lang lesing die oorspronklike is, kon die kort lesing as gevolg van homoioteleuton ontstaan het. Beide die teks onder bespreking en vers 25 eindig op dieselfde woord, ú $\mu \omega v$ (van julle). Aan die ander kant kon die woorde ook deur'n skriptor bygevoeg gewees het as gevolg van harmoniëring met Mt 6: 15. Die konteks waarin die woorde voorkom is in beide gevalle dieselfde en leen hom dus tot harmoniëring, terwyl die woorde in dispuut, veral die tweede gedeelte daarvan, feitlik woordeliks met dié van Mt 6: 15 ooreenkom. Terwyl dit moeilik is om op transkripsionele gronde alleen te besluit hoe om die getuienis te interpreteer, is die kombinasie van transkripsionele en eksterne getuienis waarskynlik 'n aanduiding dat die kort lesing die oorspronklike is.

\section{(e) Mk 15:27}

By Mk 15: 27 is daar weer 'n nota in die NAB wat sê dat die bekende vers 28, 'En die Skrif is vervul wat sê: En Hy is by die misdadigers gereken' (OAB) nie in die grondteks voorkom nie. Ook in hierdie variasie-eenheid word twee variante lesings in die kritiese apparaat gegee:

(1) Weglating: $\mathrm{X}$ A B C D X $\Psi$ Lect d k sys sa bomss enkele kerkvaders

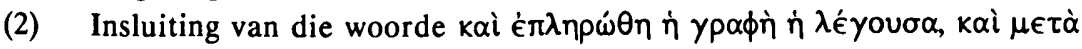

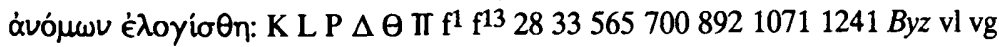
syp,h,pal bopt goth arm geo eth Orig enkele kerkvaders

Die weglating van hierdie gedeelte het verreweg die beste steun van eksterne getuienis, omdat dit in al die beste manuskripte voorkom en 'n baie wye vroeë geografiese verspreiding geniet. Daarenteen blyk uit die vroeë Latynse steun vir die lang lesing dat dit andermaal ' $n$ vroeë Westerse interpolasie is, wat deur vermenging uit die Westerse teks in die ander tekste beland het. Transkripsioneel gesien, kan homoioarkton moontlik 'n oorsaak van weglating wees, aangesien beide verse 27, 29 en die betwiste woorde met die woord kai (en) begin. Tog is die woordelikse ooreenkoms van die tweede deel van die teks met $L k$ 22: 37, wat daar as 
voorspelling van die vervulling van Jes 53: 12 , en hier as die vervulling self, vertel word, 'n aanduiding dat die lang lesing andermaal moontlik die gevolg van harmoniëring kan wees. Die effense verskil in konteks (in Lukas is dit 'n voorspelling en in Markus 'n berig van die vervulling) maak dit onwaarskynlik dat die voorkoms daarvan in Markus die bron vir Lukas se gebruik daarvan is. Eksterne en interne getuienis saam bring dus mee dat gekonkludeer moet word dat die lesing waarskynlik nie deel van nie oorspronklike teks was nie.

\section{(f) Mk 16: 8}

Ten slotte die slot van die Markusevangelie. Dit is opmerklik dat 'n voetnoot in die NAB by Mk 16: 9 voorkom, ondanks die feit dat die teks nie van die OAB verskil nie. Die probleem is dat die Markusevangelie op verskillende maniere in die manuskripte afgesluit word. In sommige manuskripte eindig dit by Mk 16: 8: '...Hulle het vir niemand anders iets daarvan gesê nie, want hulle was bang'. In ander eindig dit met die gedeelte wat in beide die OAB en NAB voorkom en as verse $9-20$ bekend staan. 'n Derde groep manuskripte bevat 'n baie kort slotgedeelte na vers 8 , wat min of meer soos volg lui: 'Maar hulle het alles wat vir hulle gesê is, kortliks vir Petrus en die ander by hom vertel. Daarna het Jesus self deur hulle die heilige en onverganklike evangelie oor die ewige redding van die ooste tot in die weste laat verkondig. Amen'. 'n Vierde groep manuskripte bevat beide die kort slotgedeelte en verse 9-20. Die kritiese apparaat van hierdie gedeelte lyk soos volg:

(1) ...é фoßoûvto yóp. (..want hulle was bang.): × B 304 sys samss armmss geo Cl Orig Eus Hier (wat in een van sy kommentare noem dat hy manuskripte ken wat hier eindig) enkele kerkvaders

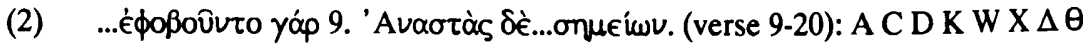
II $\mathrm{f}^{13} 28335657008921071$ Byz vl vg sy cop goth arm ${ }^{\mathrm{mss}}$ geo eth $^{\mathrm{mss}}$ Diat Ir Tert et al

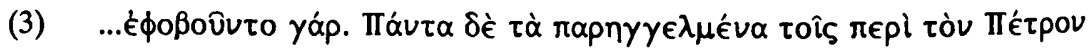

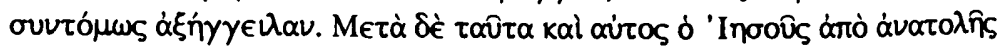

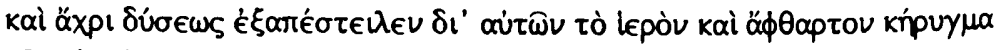

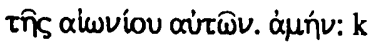

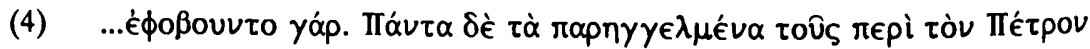

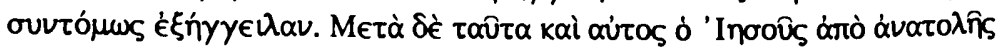

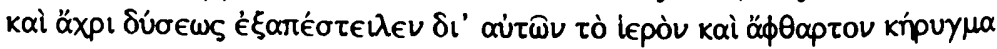

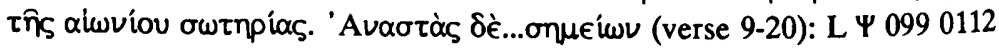
$274^{\mathrm{mg}} 579$ syh(mg) samss bo ${ }^{\mathrm{mss}}$ eth $^{\mathrm{mss}}$ 
Op grond van eksteme getuienis is dit duidelik dat dit onwaarskynlik is dat lesings 3 en 4 oorspronklik die Markusevangelie afgesluit het. Beide kom in slegs enkele bronne voor en is op transkripsionele gronde 'n duidelike poging om 'n gepaste slot vir Markus te bied. Die keuse lê dus by lesings 1 en 2. Op grond van eksterne getuienis is daar min tussen die twee lesings te kies. Hoewel lesing 1 in die oudste en beste manuskripte ( $X$ en $B$ ) voorkom, het lesing 2 'n beter geografiese verspreiding as lesing 1 . Op transkripsionele gronde swaai die skaal effens in die guns van lesing 1, aangesien daar geen oortuigende rede is waarom verse $9-20$ weggelaat sou word indien dit oorspronklik deel van die Markusevangelie was nie. Die enigste moontlike rede is dat dit per ongeluk verlore geraak het, deurdat die laaste bladsy van hierdie boek uitgeval het. Hoewel moontlik, is dit egter onwaarskynlik. Daarteenoor is die byvoeging van verse $9-20$ makliker verklaarbaar, naamlik as 'n poging om die Evangelie af te rond deur 'n gepaste slot daarvoor te voorsien. Die feit dat daar ook 'n ander slot deur skriptors geskryf is (lesing 3), en 'n kombinasie van die verskillende slotgedeeltes in sommige manuskripte voorkom (lesing 4), dui daarop dat meer as een skriptor'n probleem gehad het met die feit dat die Tweede Evangelie by vers 8 (op 'n partikel in Grieks yóp - 'immers') eindig en 'n gepaste slot voorsien het. Die sterkste getuienis kom egter van intrinsieke getuienis. Veral twee sterk argumente is ter sprake. Daar is talle taalkundige eienskappe van verse 9-20 wat nie eie aan Markus se taal en styl is nie en dus op 'n sekondêre oorsprong van die gedeelte dui. Daarmee saam blyk dit dat, indien die gedeelte teologies en inhoudelik ontleed word, dit saamgestel is uit frases en gedagtes uit die ander Evangelies, Handelinge en die Pauliniese Briewe, wat nie eie aan die Markaanse teologie is nie. Ten gunste van die lang lesing kan egter op intrinsieke gronde gevra word of 'n boek werklik op 'n partikel ( $\gamma o \alpha$ - immers) kan eindig. Verder blyk dit ook dat die storie nie voltooi is nie en dat die leser met 'n hele aantal 'los drade' gelaat word indien vers 8 as die einde van die Tweede Evangelie geag word. Op grond van veral die intrinsieke getuienis en die feit dat die oudste en beste manuskripte by vers 8 eindig, moet nieteenstaande hierdie probleme gekonkludeer word dat geeneen van lesings 2, 3 of 4 die oorspronklike slot van Markus verteenwoordig nie. Lesing 1 verteenwoordig dit op grond van die intrinsieke getuienis waarskynlik egter ook nie. Die enigste oplossing vir die probleem is om te aanvaar dat die oorspronklike slot van hierdie Evangelie op 'n baie vroeë stadium in die oorleweringsgeskiedenis verlore geraak het en dat skriptors daarvoor probeer kompenseer het deur self ' $n$ nuwe slot te skryf.

Literatuur: K Aland 1969b; Boomershine \& Bartholomew 1981; Burgon 1975a; JK Elliott 1971c; Metzger 1980c; Meye 1969; Petersen 1980; Zwemer 1975. 


\subsection{Lukas}

Een van die merkwaardigste aspekte van die teks van die Derde Evangelie raak die laaste hoofstukke van die Evangelie. Buiten die teks van Handelinge, is daar geen ander plek in die Nuwe Testament waar die verskil tussen die Alexandrynse en Westerse teks so duidelik na vore kom as in hierdie dele nie. Daar is ' $n$ hele antal gevalle waar die Westerse teks 'n langer, maar dan ook weer 'n korter teks as die Alexandrynse teks het. Dit raak gewoonlik frases en soms selfs sinne. Geen aanvaarbare teorie om hierdie verskynsel te verklaar, kon nog gevind word nie. Sommiges meen dat dit die invloed van Marcion op die teks illustreer, omdat ' $n$ hersiene weergawe van die Derde Eevangelie die enigste boek buiten 'n aantal van die Pauliniese Briewe is, wat in Marcion se kanon gestaan het. Die teorie is dan dat hierdie veranderinge die spore van Marcion se hersiening van die Derde Evangelie verteenwoordig. Andere beskou die Westerse teks egter as die oorspronklike en meen dat die Alexandrynse teks aan 'n verkorting daarvan te wyte is. Die rede daarvoor is nie bekend nie.

Onder die merkwaardige publikasies van die Lukasevangelie is die teks van die IGNTP, wat in twee volumes in 1984 en 1987 verskyn het, en wat 'n volledige apparaat van die Lukasevangelie bevat. Ook vir die Derde Evangelie is die teks van Jülicher, Matzkow en Aland die enigste bron van die lesings van die oud-Latynse manuskripte. Die oudste bronne van die Lukasevangelie is die volgende:

2de eeu: Diat; 3de eeu: $\mathrm{P}^{3,4,45,69,75} 0212$ sa; 4de eeu: $\mathrm{P}^{7,82} \times$ B W 01710181 a sys,c ac bo $\mathrm{mf}$ goth.

Litcratuur: Amphoux 1987; Baarda 1985; 1988b; Bailey 1977; Bandstra 1981; 1982; Bartsch 1984; Bate 1927; Chadwick 1957; Cooper 1962; Cortés 1984; Duplacy 1981; Ehrman \& Plunkett 1983; JK Elliott 1988a; Epp 1981; Fee 1981; Freudenberger 1968/69; Geerlings 1961a; 1962b; 1968b; Globe 1980; Jordaan 1980; 1986; Jülicher, Matzkow \& Aland (eds) 1976; Kilpatrick 1942b; 1946; 1952/53; 1979b; Klijn 1981; Metzger 1968g; P Parker 1964; Parsons 1986; Petzer 1984b; Rese 1976; Rice 1979; 1980a; 1980b; Richards 1979; 1981; Ross 1972; Royse 1980; Schneider 1976; Stagg 1978; Van Bruggen 1980; 1982; Vogels 1950/51; Voöbus 1968/69; Wisse 1982.

\section{(a) Lk 2: 14}

In die vertelling van die engelesang tydens Jesus se geboorte in Lk 2 is daar 'n variasie-eenheid wat 'n direkte invloed op die vertaling van die gedeelte het. Die vraag is naamlik of die engele in Lk 2: 14 gesing het 'vrede ... vir die mense in wie Hy ' $n$ welbehae het' (NAB) of 'vrede ... in die mense ' $n$ welbehae' (OAB)? Is die vrede op 
aarde dus bedoel vir alle mense (OAB) of slegs 'n klein groepe (NAB)? Die variasie-eenheid in Grieks raak slegs 'n enkele letter:

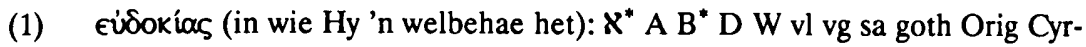
Jer Ir Ath Aug

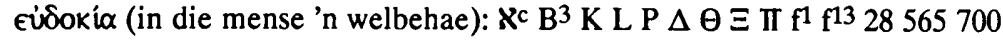
89210711241 Byz Lect syh,p,s bo arm eth geo Orig Eus Did en 'n aantal kerkvaders

Dit is duidelik dat lesing 1 hier die beste eksteme getuienis het, aangesien dit in al die beste dokumente voorkom, terwyl dit ook vroeg 'n wye geografiese verspreiding geniet. Dit kom naamlik in die vroegste bronne van alle gebiede behalwe die Siriese vertalings voor. Dit word veral sterk deur die twee onafhanklike vroeë tekstipes, die Westerse en Alexandrynse, ondersteun. Lesing 2 se vroegste bronne is beperk tot die Caesareaanse tekstipe en die Siriese vertaling, vanwaar dit waarskynlik na die Bisantynse teks oorgedra is. Omdat die variasie slegs een letter in Grieks raak, is die ontstaan van die variasie waarskynlik aan 'n toevallige fout toe te skryf. Terwyl daar op transkripsionele gronde geen werklike rede vir die byvoeging van die letter $(\sigma)$ is nie, kan die weglating daarvan maklik verklaar word as synde te wyte aan 'n sigfout. Dikwels is so 'n slotsigma bloot as 'n klein verhewe lettertjie geskryf: EY $\triangle O K I A$ c, wat maklik deur'n skriptor misgelees kon word.

Literatuur. Kilpatrick 1988; Schwarz 1984.

\section{(b) Lk 17: 35}

By Lk 17: 35 kom daar in die NAB 'n voetnoot voor wat sê dat vers 36 van die OAB nie in die grondteks voorkom nie. Dit raak die tradisioneel bekende woorde: 'Twee sal op die land wees; die een sal aangeneem en die ander verwerp word'. Die tekskritiese apparaat van die vers is soos volg:

(1) Weglating van vers 36: $\mathrm{P}^{75} \times \mathrm{A}$ B K L W X $\Delta \Theta \Pi \Psi \mathrm{f}^{1} 2833565892$ et al Byz sa bo goth eth enkele kerkvaders

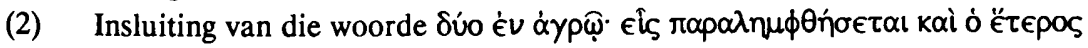

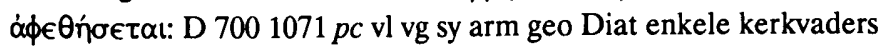

Dit is duidelik dat eksterne getuienis lesing 1 feitlik ten volle steun. Dit het met die uitsondering van die Westerse teks ondersteuning uit alle tekstipes, sowel vroeg as 
laat. Die insluiting van die gedeelte (lesing 2) het in teenstelling daarmee slegs steun uit die Westerse en gedeeltelike steun uit die Caesareaanse tekstipe. Die transkripsionele getuienis is verdeel, wanneer dit in isolasie van eksterne getuienis beskou word. Terwyl die weglating toegeskryf kan word aan homoioteleuton - die herhaling van $\alpha \phi \in \theta n \dot{n} \sigma \in \tau \alpha l$ (verwerp word) aan die einde van vers 35 en die woorde in dispuut - kan die byvoeging ook verklaar word as synde 'n poging om hierdie teks met dié van Mt 24: 40 te harmonieer. Wat veral in die guns van laasgenoemde tel, is die feit dat Matteus die bron van die harmoniëring is, wat dus met die algemene neiging in harmoniëring ooreenkom, en die feit dat die harmoniëring in veral die Westerse teks voorkom, wat weer 'n tipiese karakteristieke eienskap van hierdie teks is. Op grond hiervan sal die kort lesing dus as die oorspronklike gekies word.

\section{(c) Lk 23: 16}

By Lk 23: 16 is daar in die NAB 'n nota waarin verklaar word waarom daar nie 'n vers 17 voorkom nie. Die woorde van vers 17 lui in die OAB soos volg: 'En hy was verplig om vir hulle op die fees een los te laat'. Die tekskritiese apparaat by hierdie gedeelte lyk soos volg:

(1) Weglating: P75 A B K L T Tा 892* 1241 pc a sa bo ${ }^{\text {mss }}$ Diat

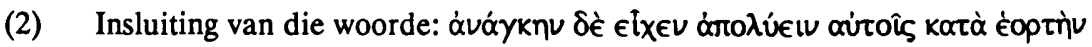
Ěva met variasie (En hy was verplig om vir hulle een op die fees los te laat): X W X $\Delta \Theta \Psi \mathrm{f}^{1} \mathrm{f}^{13} 28565700892^{\mathrm{mg}} 1071$ Byz Lect vl vg syp,h bo ${ }^{\mathrm{mss}}$ arm geo Eus

(3) Insluiting van dieselfde woorde as in 2, maar na vers 19: D d sycs, eth

Beide vanuit die oogpunt van die oudste en beste manuskripte en die geografiese verspreiding ondersteun eksterne getuienis lesing 1, omdat dit, met die uitsondering van $X$, in al die beste manuskripte voorkom terwyl dit 'n matige vroeë ondersteuning uit alle gebiede geniet. Aan die ander kant geniet lesing 2 ook'n wye geografiese verspreiding deurdat dit in vroeë dokumente van alle tekstipes, selfs die Alexandrynse teks $(\boldsymbol{N})$, voorkom. Tog kan die meeste van hierdie bronne aan die Westerse teks en sy invloed verbind word. Lesing 3 is duidelik tot die Westerse teks beperk en daarom op eksterne gronde nie aanvaarbaar nie. Uit ' $n$ transkripsionele oogpunt beskou, is die getuienis botsend. Die weglating kan verklaar word na

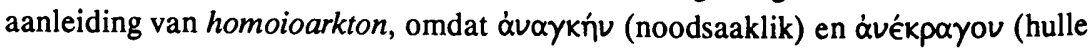
het geskree) van vers 18 baie na mekaar lyk. Aan die ander kant pas die lang lesing weer binne die kenmerkende eienskappe van die Westerse teks, aangesien dit na 'n 
tipiese Westerse byvoeging lyk, wat moontlik hier ingesluit is in 'n poging om die Lukas-vertelling met dié van Mt 27: 15 of Mk 15: 6 te harmonieer. As sodanig is dit 'n poging om die Lukaanse vertelling af te rond, deur 'n stukkie 'ontbrekende historiese detail' by te voeg.

\subsection{Johannes}

Van die Johannesevangelie bestaan daar nog geen volledige apparaat nie. Die verteenwoordigers van die IGNTP het na afhandeling van die Lukas-projek besluit om onmiddellik met die Johannesevangelie te begin. Die projek is tans in die beplanningstadium. Sover dit die oud-Latynse teks betref, voltooi die uitgawe van Johannes deur Jülicher, Matzkow en Aland hierdie besondere reeks. Die oudste bronne van die Johannesevangelie is die volgende:

2de eeu: P52 Diat; 3de eeu: P5,22,28,39,45,66,75,76,80 0162 sa; 4de eeu: P6 $\times$ B W 0258 a sycs, bo $\mathrm{mf}$ goth.

Literatuur: Agourides 1967; K Aland 1957b; Birdsall 1957b; 1957/58; DA Black 1985; KW Clark 1962; JK Elliott 1977b; Fee 1968/69; 1971a; 1971b; 1974a; 1980b; Geerlings 1962a; 1963; Hahn 1976; Jülicher, Matzkow \& Aland (eds) 1963; Kilpatrick 1960b; 1960c; 1968; Mees 1969; 1981; Michaels 1981; EL Miller 1976; Porter 1967; Pryor 1985; Reim 1976; Sahlin 1960; Schedle 1972; Schnackenburg 1976; Tasker 1936; Thomas 1987; Van Belle 1980.

\section{(a) Jh 1: 18}

In Jh 1: 18 is daar 'n subtiele verskil tussen die twee Afrikaanse vertalings. Terwyl die OAB lees: 'die eniggebore Seun', lees die NAB 'Sy enigste Seun, self God'. 'n Meer letterlike vertaling vir die teks waarop die NAB gegrond is, sou wees: 'Die enigste God'. Die apparaat vir hierdie variasie-eenheid is soos volg:

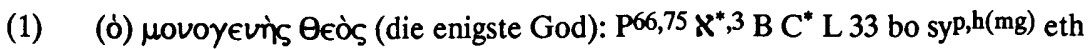
Diat Ir Cl Orig Did en 'n hele aantal kerkvaders

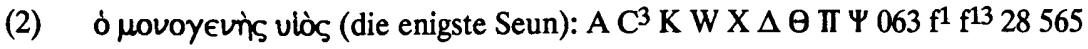
70089210711241 Byz Lect vl vg syc,h,pal arm eth geo en baie kerkvaders

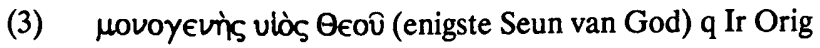

(4) ó Movoyevins (die enigste) vg Diat en 'n aantal kerkvaders

Die laaste twee lesings ( 3 en 4) kan maklik uitgeskakel word op grond van die feit 
dat hulle slegs in vertalings en patristiese sitate voorkom. Lesing 3 is duidelik ' $n$ poging om deur middel van konflasie lesings 1 en 2 in harmonie met mekaar te bring, terwyl lesing 4 dieselfde probeer doen, maar wel deur die problematiese deel van die lesing weg te laat. Dit laat dus lesings 1 en 2 . Op grond van eksterne getuienis het lesing 1 'n baie sterk aanspraak om die oorspronklike te verteenwoordig, omdat dit in al die vroegste en beste bronne voorkom ( $\mathrm{P}^{66,75} \times \mathrm{B}$ ) en 'n goeie vroeë geografiese verspreiding geniet. Dit kom naamlik in alle geografiese gebiede voor, ofskoon dit in die Westerse en Caesareaanse tekste skrapse steun geniet. Lesing 2, daarenteen, is beperk tot veral Westerse bronne in die vroegste eeue, vanwaar dit deur middel van vermenging eers in bronne van die Caesareaanse teks en later die Bisantynse teks, ingesluit is. Op transkripsionele gronde is dit duidelik dat $\theta \epsilon o ́ \varsigma$ (God) hier die moeilikste lesing is en dat die verandering na viós (seun) makliker verklaar kan word as andersom. Waarskynlik het die lesing met die ontwikkeling van die teologie rondom Jesus in die vroeë kerk meegebring dat 'n skriptor of probeer het om die eksegetiese betekenis hier duideliker en meer eksplisiet te mak deur die kontras tussen Vader en Seun in die vers te beklemtoon, of probeer het om 'n 'fout' in sy archetipe te herstel deur Eeós (God) met viós (Seun) te vervang. Daar is egter geen duidelike rede waarom iemand viós (Seun) na Ө€ós (God) sou wou verander nie. Die probleme wat die lesing Oeós (God) ook vir die Afrikaanse vertalers gebring het, bevestig dat dit die moeilike lesing is. In 'n poging om die betekenis daarvan duidelik na vore te bring, het hulle in der waarheid lesing 3 vertaal.

Literatuur. McReynolds 1981.

\section{(b) Jh 5:3}

In Jh 5 ontbreek in die NAB waarskynlik een van die langste tradisioneel bekende gedeeltes van die Nuwe Testament, naamlik dít wat in die OAB as Jh 5: $3 \mathrm{~b}-4$ bekend gestaan het en soos volg gelui het: 'Want 'n engel het op bepaalde tye neergedaal in die bad en die water geroer. Die een wat dan eerste ingaan na die roering van die water, het gesond geword, aan watter siekte hy ook al gely het.' Die tekskritiese apparaat van hierdie variasie-eenheid lyk soos volg:

(1) Weglating: P66,75 $\times$ B C $C^{*} D$ W $33 \mathrm{~d}$ f I q vg syc sa bo geo $p c$

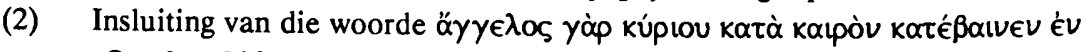

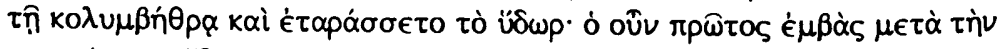

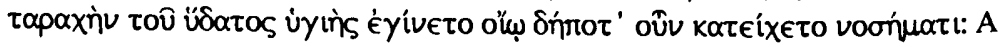


$\mathrm{C}^{3} \mathrm{~K}$ L S X $\Delta \theta \wedge \Pi \Psi \mathrm{f}^{1} \mathrm{f}^{13} 2856570089210711241$ pm Byz Lect vlpm vg syh,p,pal bo ${ }^{\mathrm{mss}}$ arm Diat Tert Did Chrys en enkele kerkvaders (sommige van hierdie bronne sluit dit met ' $n$ asterisk in)

Op eksteme gronde is lesing 1 duidelik bo lesing 2 te verkies, omdat dit in al die oudste en beste manuskripte ( $\mathrm{P} 66,75 \times \mathrm{B}$ sa) voorkom, sowel as in manuskripte van elke tekstipe. Dit sluit die Caesareaanse teks, waarvan die bestaan in Johannes in elk geval twyfelagtig is, uit. Ten opsigte van die vroegste getuienis, is die bronne van lesing 2 geografies tot Westerse bronne beperk, vanwaar dit na die Caesareaanse teks en later Bisantynse teks oorgegaan het. Die transkripsionele getuienis bevestig hierdie rekonstruksie. Terwyl daar geen rede is waarom die woorde deur 'n skriptor weggelaat sou word indien dit in die oorspronklike weergawe van die Vierde Evangelie was nie, pas dit baie duidelik in die Westerse teks se neiging om 'ontbrekende detail' by te voeg. Dit is waarskynlik 'n poging om die genesingskrag van die bad se water te verklaar. Die woorde is waarskynlik uit die mondelinge tradisie afkomstig en was moontlik aanvanklik 'n marginale glos, bedoel as kommentaar, voordat dit vandaar by die teks van 'n latere manuskrip ingesluit is. Ook intrinsieke getuienis bevestig die sekondêre karakter van hierdie gedeelte, aangesien daar 'n besonder hoë konsentraat woorde en taalkundige verskynsels in hierdie teks voorkom wat nie eie aan die algemene woordeskat en taalgebruik van Johannes is nie. Op grond hiervan was hierdie woorde waarskynlik nie deel van die oorspronklike teks van die Vierde Evangelie nie.

Literatuur. Fee 1982a; Hodges 1979a.

\section{(c) Jh 7:53}

Die enigste voorbeeld van twyfel oor 'n hele paragraaf naas die slot van die Tweede Evangelie, kom in die Johannesevangelie voor. Die hele vertelling van Jesus se gesprek met die owerspelige vrou in Jh 7: 53-8: 11 is in gedrang en hoewel die teks nie in die NAB ontbreek nie, is ook hierdie gedeelte, soos die slot van Markus, van 'n voetnoot voorsien. Daarin word gesê dat dit nie deel van die oorspronklike Johannesevangelie was nie. Die kritiese apparaat by hierdie teks is soos volg:

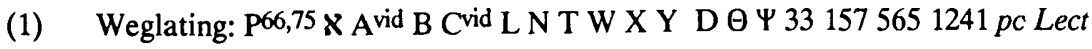
a f $\mathrm{l}^{*} \mathrm{q}$ syc,s,p sa bo ${ }^{\mathrm{mss}}$ ac goth armmss geo Diat en $\mathrm{Cl}$ Tert Orig Cy Chry en enkele kerkvaders

(2) Insluiting van die gedeelte op die tradisionele plek, Jh 7: 53-8: 11: D E F G 
H K M S U Г ^ Tा 287008921071 Byz vlpm vg syh(ms),pal bo ${ }^{\text {mss }}$ arm eth Hier Aug en enkele kerkvaders (enkele van hierdie bronne sluit dié met 'n asterisk in)

(3) Insluiting van die gedeelte na Jh 7: 36: 225

(4) Insluiting van die gedeelte aan die einde van die Vierde Evangelie (na Jh 21: 25): $\mathrm{f}^{1}$ arm

(5) Insluiting van die gedeelte in die Lukasevangelie (na Lk 21: 38): $\mathrm{f}^{13}$

(6) Insluiting van die gedeelte aan die einde van die Lukasevangelie (na Lk 21: 53): $1333 \mathrm{c}$

Dit is uit die bestaan van soveel verskillende lesings duidelik dat daar lank in die teksgeskiedenis onsekerheid oor die posisie van hierdie perikoop was. Die feit dat dit op vyf verskillende plekke in die Nuwe Testament voorkom, getuig hiervan. Op grond van die skaars getuienis kan lesings 3, 4, 5 en 6 verwerp word. Elkeen is waarskynlik 'n eie poging om die perikoop as deel van die teks te behou, maar dit op 'n meer geloofwaardige plek in te sluit in 'n poging om die probleme wat dit in Jh 7 veroorsaak, die hoof te bied. Daarom sal net lesings 1 en 2 verder oorweeg word. Op eksterne gronde is dit duidelik dat lesing 1 'n groter aanspraak het om die oorspronklike te verteenwoordig as lesing 2 . Nie alleen kom dit in al die beste manuskripte voor nie ( $\mathrm{P} 66,75 \times \mathrm{B} \mathrm{sa})$, maar dit kom ook in die vroegste manuskripte van al die teksfamilies (selfs die Bisantynse teks - W en A) voor. Tot laat in die 3de eeu is die Johannesevangelie waarskynlik sonder hierdie perikoop oorgelewer. Daarenteen is die vroegste getuienis ten gunste van die insluiting van die gedeelte in die Vierde Evangelie (lesing 2) eers in die 4de of 5de eeu gedateer en is dit in alle gevalle tot die Westerse teks beperk. Op grond van besonder sterk eksterne getuienis is dit baie duidelik dat hierdie perikoop na alle waarskynlikheid eers teen die 3 de of 4 de eeu deel van die teks van die Vierde Evangelie geword het. Op transkripsionele gronde is dit moeilik om 'n beslissing te maak. Aan die een kant kan die weglating van die gedeelte gewyt word aan 'n bladsy wat uit 'n kodeks verlore geraak het. Die probleem hiermee is dat dit, teen die agtergrond van die eksterne getuienis, baie moeilik verklaar kan word waarom soveel onafhanklike bronne voor die 4de eeu so totaal oor die bestaan van die perikoop swyg, en waarom en vanwaar dit nou juis teen die einde van die 3 de eeu skielik weer na vore getree het. Hoewel die byvoeging van die gedeelte mooi inpas in die neiging om ontbrekende detail by te voeg, is dit aan die ander kant moeilik om 'n werklike rede te vind waarom iemand juis dít sou wou byvoeg. In die lig van die bestaan van ook ander bekende buite-Bybelse mondelinge en skriftelike stories oor Jesus, wat nie in manuskripte van die Evangelies voorkom nie, sal verklaar moet word waarom juis hierdie storie 
sy weg tot in die teks gevind het. Daar is oënskynlik geen duidelike rede nie. Transkripsionele getuienis bied dus in hierdie geval geen oplossing nie. Verdere ondersteuning vir die eksterne getuienis ten gunste van die kort lesing (lesing 1) kan egter in duidelike intrinsieke getuienis gevind word. In die eerste plek bevat die taal en styl van die betrokke gedeelte 'n besonder hoë persentasie non-Johannese elemente, terwyl die gedeelte uit 'n strukturele oogpunt beskou, ook in die konteks problematies is. Dit sluit tematies nie by die voorafgaande of daaropvolgende gedeelte aan nie. Op hierdie gronde moet dus gekonkludeer word dat die oorspronklike Johannesevangelie nie die vertelling van Jesus se gesprek met die owerspelige vrou bevat het nie, maar dat dit 'n latere byvoeging was.

Literatuur. Burgon 1975b; Ehrman 1988a; Hodges 1979b; Salvoni 1960.

\section{HANDELINGE}

In die oorleweringsgeskiedenis van Handelinge kom een van die mees basiese probleme in die Nuwe-Testamentiese Tekskritiek tot 'n kulminasiepunt. Die probleem bestaan in die algemeen daaruit dat daar oënskynlik geen logiese historiese verklaring vir die verskille tussen die Alexandrynse en Westerse tekste is nie. Die karakteristieke eienskappe van hierdie twee tekste bereik 'n kulminasiepunt in Handelinge, deurdat die Westerse teks van hierdie boek ongeveer tien persent langer as die Alexandrynse teks is. Daar is geen duidelike verklaring vir die ontstaan en bronne van enige van die twee tekste, indien die ander as die oorspronklike aanvaar word nie. Gevolglik het hierdie probleem in die verlede tot 'n hele aantal verklarings gelei: (a) Die mees gangbare teorie, wat vandag algemeen aanvaar word, is dat die Alexandrynse teks die oorspronklike verteenwoordig, terwyl die Westerse teks die gevolg van 'n hersiening daarvan deur skriptors is. Wat die bron van die hersiening is, is egter nie duidelik nie. (b) Ander meen weer dat die Westerse teks die oorspronklike is en dat die Alexandrynse teks 'n verkorting daarvan is. (c) Die mees radikale teorie lui dat die skrywer van Handelinge aanvanklik die kort (Alexandrynse) teks geproduseer het en self later 'n tweede uitgawe daarvan voorberei het, deur dit uit te brei. Al hierdie (en nog ander) teorieë oor die teksgeskiedenis van hierdie boek verklaar sekere aspekte van die probleem, maar laat andere onverklaar. Hierdie is daarom steeds een van die grootste probleme in die Nuwe-Testamentiese Tekskritiek. Dit is egter ook een van die interessantste en mees besproke aspekte van hierdie wetenskap.

Onder die merkwaardige uitgawes van die teks van Handelinge is dié deur $A C$ Clark in 1933, wat op die teorie gegrond is dat die Westerse teks die 
oorspronklike teks bevat. Die Handelingeteks het sedert die sewentigerjare skielik nuwe belangstelling gaande gemaak. Dit is byvoorbeeld duidelik uit die verskyning van die uitgawe van Boismard en Lamouille, wat 'n rekonstruksie van beide die Alexandrynse en Westerse tekste bevat en gegrond is op die teorie dat die skrywer beide weergawes voorberei het. Voorts word daar tans by die Abilene Christian University in Abilene, VSA, onder leiding van Carroll Osburn aan 'n projek gewerk om 'n kritiese teks met ' $n$ volledige apparaat daar te stel. Daar bestaan geen uitgawe van die Vetus Latina-teks van Handelinge nie. Die oudste bronne van Handelinge is die volgende:

2de eeu: 0189; 3de eeu: $P^{29,48,53}$ sa; 4de eeu: $P^{8,38,50,57} \times$ B 0570244 bo mf goth.

Literatuur: Barrett 1979; Birdsall 1958; M Black 1981; Boismard 1981; Boismard \& Lamouille 1987; Boismard \& Lamouille (eds) 1984; AC Clark 1970; JK Elliott 1988d; Epp 1962; 1966a; 1966b; 1981; Geer 1988; Haenchen 1957; Haelewyck 1988; Hanson 1965/66; Jülicher 1914; Kilpatrick 1943; 1963c; 1977a; 1979b; 1986; Klijn 1959a; 1959b; 1966; 1969; Pack 1960d; P Parker 1964; Parsons 1988; Petzer 1988b; Riesenveld 1979; Sanders 1937a; 1937b; Schneider 1987; Thiele 1965a; Wikgren 1951; 1981; Willis 1968.

\section{(a) Hd 8: 36}

In die vertelling van die bekering van die Ethiopiër in $\mathrm{Hd} 8$ ontbreek 'n baie bekende vers in die NAB. Dit het in die OAB as Hd 8: 37 bekend gestaan en soos volg gelui: 'Toe sê Filippus: As jy glo met jou hele hart, is dit geoorloof. En hy antwoord en sê: Ek glo dat Jesus Christus die Seun van God is'. Die tekskritiese apparaat van hierdie vers is soos volg:

(1) Weglating: P45,74 א A B C II 33'vid $8188^{*} 1813266141241$ pm Byz Lect vg syp,h sa bo eth Chry

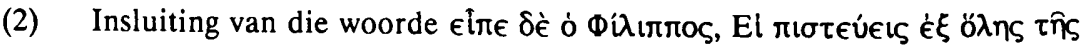

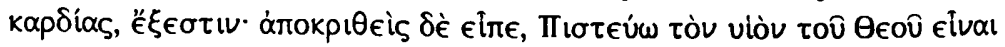

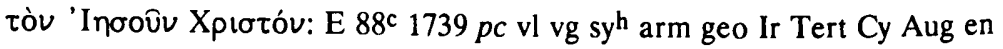
enkele kerkvaders (sommige van hierdie bronne het die lesing in 'n effens gewysigde vorm)

Dit is met die eerste oogopslag duidelik dat eksterne getuienis die kort lesing (lesing 1) ondersteun, omdat dit in die oudste en beste bronne van Handelinge voorkom ( $\mathrm{P}^{74} \times \mathrm{B}$ sa) en 'n vroeë wye geografiese verspreiding geniet. Met die uitsondering 
van die oud-Latynse vertaling, 'n belangrike deel van die Westerse teks, kom dit in vroeë getuienisse van alle geografiese gebiede voor. Transkripsionele getuienis ondersteun ook die kort lesing (lesing 1), omdat dit makliker is om die byvoeging van die gedeelte te verklaar as die weglating daarvan. Daar is oënskynlik geen rede waarom die teks weggelaat sou word indien dit die oorspronklike is nie. As 'n byvoeging pas dit egter baie mooi binne die tendense in die Westerse teks van Handelinge, waarin die lang lesing ook sy vroeë steun het. Die bron vir die lang lesing is waarskynlik die doopsformules in die liturgie van die vroeë kerk, waaruit dit saamgestel en by die teks ingesluit is. Ook intrinsieke getuienis ondersteun lesing 1 , omdat daar tekens van nie-Lukaanse taalgebruik in die teks voorkom. Veral die frase tòv 'Inooûv Xplotóv lyk in hierdie opsig verdag.

\section{(b) Hd 15: 33}

Hd 15: 33 is in die NAB van 'n voetnoot voorsien, waarin gestel word dat dit wat tradisioneel as vers 34 bekend was, nie in die grondteks voorkom nie. Die volgende woorde van die OAB ontbreek dus in die NAB: 'Maar Silas het besluit om daar te bly'. Die kritiese apparaat van hierdie gedeelte lyk soos volg:

(1) Weglating: P74 $\times$ A B E P \& 811046141241 pm Byz e p vg syp,h bo Chrys

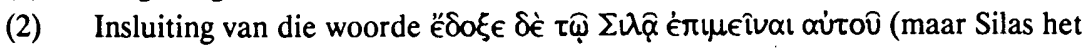
besluit om daar te bly): C 33881813266141739 pc c syh sa bo ${ }^{\text {mss }}$ arm geo eth twee kervaders

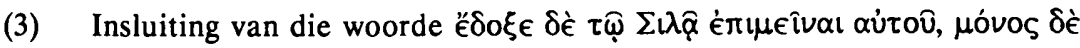

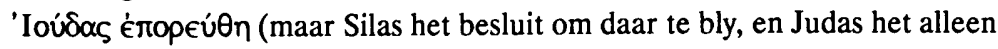
vertrek): D ar d gig $1 \mathrm{ph}$ w vg (met kleiner variasie)

Onder die lesings in hierdie variasie-eenheid is lesing 3 op veral eksterne gronde as 'n sekondêre byvoeging te verwerp. Dit pas baie mooi binne die raamwerk van die Westerse interpolasies in Handelinge en kom ook net in Westerse getuienisse voor. Dit is duidelik dat lesing 2 die bron van lesing 3 was en dat die byvoeging van die frase dat Judas alleen na Jerusalem teruggekeer het, waarskynlik 'n poging deur Westerse skriptors verteenwoordig om die betekenis van die passasie af te rond. Tussen lesings 1 en 2 is die eksterne getuienis ietwat verdeeld, hoewel dit tog as ondersteuning vir lesing 1 aanvaar kan word. Terwyl die beste Griekse bronne lesing 1 ondersteun ( $\mathrm{P}^{74} \times \mathrm{A}$ B) en dit 'n redelike goeie geografiese verspreiding geniet, is daar ook enkele van die beste manuskripte wat lesing 2 bevat (byvoorbeeld die Sahidiese vertaling). Op grond van transkripsionele getuienis sal lesing 1 waarskynlik 
ook bo lesing 2 verkies word, hoewel ook dit effens verdeeld is. Aan die een kant kon die kort lesing deur middel van homoioteleuton ontstaan het. Beide die problematiese teks en die voorafgaande vers (33) eindig op dieselfde of feitlik dieselfde woord: au่tov (van hom) of aùroús (hulle). Aan die ander kant is die byvoeging ook te verklaar uit 'n poging om historiese detail by te voeg. Dit mag ook 'n poging verteenwoordig om agtergrond vir vers 40 te bied en te verklaar hoe Silas in Antiochië te lande gekom het. Die vraag ten opsigte van laasgenoemde is egter waarom dit juis hier, en nie nader aan vers 40 nie, ingevoeg is. Terwyl dit 'n baie moeilike probleem is om op te los, sal die kort lesing hoofsaaklik op grond van eksterne getuienis waarskynlik as die oorspronklike gekies word.

\section{(c) Hd 24: 6}

In Hd 24: 6 is daar 'n nota in die NAB wat sê dat vers 7 van die OAB in die grondteks ontbreek. Die probleem raak in der waarheid meer as net vers 7 en begin reeds by vers $6 \mathrm{~b}$, terwyl dit by vers $8 \mathrm{a}$ eindig. Hierdie vers het soos volg in die $O A B$ gelui: '(6b) en wou hom volgens ons wet oordeel; (7) maar Lisias, die hoofoffisier het gekom en hom met groot geweld uit ons hande weggeneem (8a) en bevel gegee dat sy beskuldigers voor u moet kom'. Die kritiese apparaat van hierdie gedeelte lyk soos volg:

(1) Weglating: P74 $\mathrm{N}$ A B P 813261241 pm Byzpt p* s vg sa bo geo

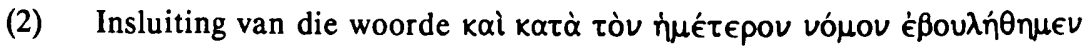

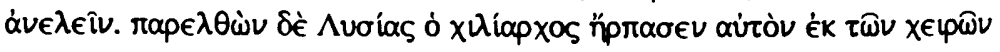
i்

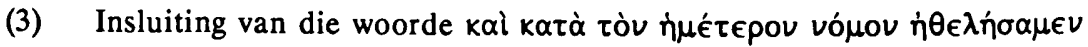

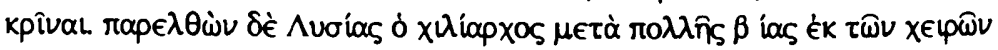

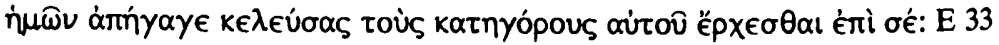
1041816146291739 Byzpt ar c e gig pc ph vg syp,h arm eth Chrys

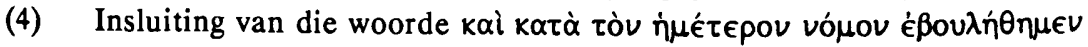

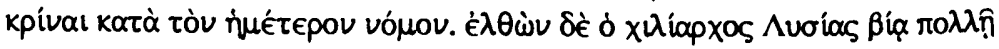

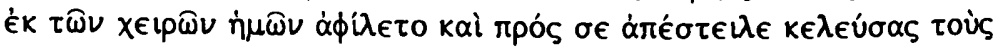

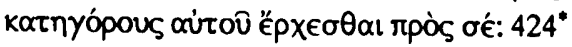

Lesings 2 en 4 kan maklik op grond van eksterne getuienis uitgeskakel word. Die feit dat elkeen in slegs een minuskel voorkom, laat die vermoede ontstaan dat hulle die gevolg van onnoukeurige kopieerwerk van die betrokke twee skriptors is. Vir beide was lesing 3 waarskynlik die bron. Lesing 1 is op eksterne gronde duidelik bo lesing 
3 te kies, omdat dit in al die oudste en beste manuskripte ( $\mathrm{P}^{74} \times \mathrm{A} \mathrm{B} \mathrm{sa}$ ) voorkom en ook 'n goeie vroeë geografiese verspreiding geniet. Dit kom naamlik voor in bronne van al die teksfamilies van Handelinge. Lesing 2, daarenteen, se vroeë steun is beperk tot die Westerse teks en dit kan daarom verwag word dat ook hierdie teks 'n Westerse interpolasie is. Transkripsionele getuienis lewer geen duidelike getuienis nie. Hoewel daar geen rede vir die weglating van die verse is nie - daar is nie tekens van homoioteleuton of homoioarkton nie en die verse bevat ook geen ooglopende teologiese probleme nie -, is die enigste moontlike rede vir die byvoeging die feit dat dit moontlik die konteks waarin dit staan, kan afrond. As sodanig pas dit binne die raamwerk van die Westerse teks, waarin dit aanvanklik bygevoeg is. Intrinsieke getuienis kan ook as ondersteuning vir die kort lesing geneem word, hoewel ook dít geen duidelike getuienis bied nie. Op grond van strukturele oorwegings in die konteks kan dit as ondersteuning van die kort lesing aanvaar word. In vers 6 en aan die begin van vers $8 \mathrm{kom}$ drie betreklike voornaamwoorde voor, wat elkeen na Paulus verwys: '(ס̋) hy wat die tempel probeer ontheilig het, (öv) wat ons gevange geneem het, ( $\pi \propto \rho^{\prime}$ ov̂) van wie u self kan uitvind'. Indien lesing 2 as oorspronklik geneem word, verander die verwysing van die laaste betreklike voornaamwoord na Lisias, wat die patroon breek. Aan die ander kant is ook gesê dat die frase ôv kà

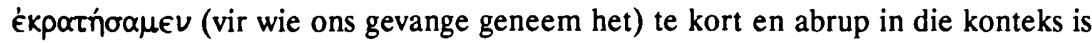
en dat dit 'n uitbreiding soos die lang lesing nodig het. Hoewel die getuienis dus ietwat verdeeld is, sal lesing 1 hoofsaaklik op grond van die eksterne getuienis en die feit dat die weglating van die lang lesing moeilik verklaarbaar is, as die oorspronklike gekies word.

\section{(d) Hd 28: 28}

In die laaste verse van Handelinge is daar twyfel oor 'n teksvers, wat ook in die $\mathrm{NAB}$ van 'n voetnoot voorsien is. Dit gaan om die woorde 'En toe hy dit gesê het, het die Jode, onder groot woordestryd met mekaar, weggegaan'. Die kritiese apparaat is soos volg:

(1) Weglating: P74 $\times$ A B E $\Psi 04833811816291739$ e s vg syh,p sa bo arm eth geo

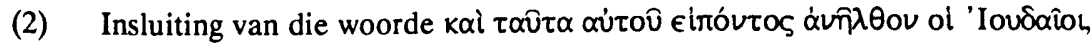

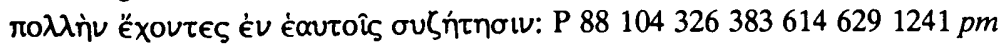
Byz Lect vl vg syh Chrys en enkele kervaders

Eksterne getuienis is ten gunste van lesing 1, omdat dit in die oudste en beste 
manuskripte voorkom, maar ook 'n baie wye vroeë geografiese verspreiding geniet. Lesing 2 daarenteen is duidelik 'n vroeë Westerse interpolasie, vanwaar dit deur middel van vermenging na bronne van ander latere tekstipes oorgedra is. Ook transkripsionele getuienis ondersteun lesing 1 , wat 'n karaktertrek van die Westerse teks openbaar, naamlik om af te rond. Die teks is waarskynlik ingevoeg om die konteks makliker te laat vloei en die oënskynlik abrupte oorgang van vers 28 na 30 beter te laat vloei.

\section{DIE PAULINIESE BRIEWE}

Onder die Pauliniese Briewe word in die Nuwe-Testamentiese Tekskritiek alle Briewe in die Nuwe Testament wat as Pauliniese Briewe oorgelewer is, beskou. Daarom word die Pastorale Briewe, die brief aan die Hebreërs, en enkele andere, waarvan die Pauliniese outeurskap bevraagteken word, ook onder hierdie hoof geplaas.

Oor die algemeen is baie min aandag aan die teks van die Pauliniese Briewe gegee. Om die een of ander rede staan hulle nie in die brandpunt van die NuweTestamentiese Tekskritiek nie. Daar is egter tog een saak ten opsigte van hierdie corpus wat vermelding verdien. Dit is die nou verweefdheid van die tekskritiese en historiese probleme in die Pauliniese briewe. Literêre probleme, soos die teorieë dat die 2 de Korintiërbrief deur 'n latere redaktor uit 'n aantal vroeëre briewe saamgestel is en die kwessie van die interpolasies in Pauliniese Briewe, bring mee dat dit nie altyd moontlik is om suiwer tekskritiese keuses te maak nie. Dit is dikwels onseker of die variasie in die manuskripte betrekking het op die teks voordat dit redaksioneel verwerk is, en of dit op die finale teks betrekking het nie. 'n Goeie voorbeeld daarvan is die slot van die Romeinebrief, wat, soos die slot van die Markus-Evangelie en die teks van Handelinge moontlik ook 'n historiese eerder as tekskritiese probleem kan wees. Die doksologie (Rm 16: 25-27) kom naamlik op verskillende plekke in hoofstukke 14, 15 en 16 in die manuskripte voor. Dit is gevolglik onseker presies waar die brief in die oorspronklike teks geeïndig het.

Daar het tot dusver geen noemenswaardige Griekse teks van hierdie briewe verskyn nie. Daar is egter wel twee studies oor hul teks wat vermelding verdien. Die eerste is dié van Gunther Zuntz oor die Pauliniese Briewe in die algemeen. Die tweede is dié van Keith Elliott, wat interne aspekte van die Pastorale Briewe in detail beskryf. Beide hierdie twee werke moet as standaardwerke oor hierdie boeke beskou word. So ver as wat dit die Vetus Latina aangaan, is die Pauliniese Briewe in 'n beter posisie as enige ander boek in die Nuwe Testament, daar sekere boeke daarvan (almal buiten die Romeinebrief, die twee Korintiërbriewe en die 
Galasiërbrief) in die Vetus Latina-reeks van Beuron verskyn het. Hermann Frede was in elke geval die samesteller.

Literatuur: Davies 1968; Frede 1964; 1976; Frede (ed) 1962-1971; 1975-1988; Kilpatrick 1944b; 1980; Nevius 1968; Osburn 1982; Quinn 1974; Walker 1987; 1988; Zuntz 1953.

\subsection{Die lang Briewe}

Die oudste bronne van die drie groot of lang Pauliniese Briewe is die volgende:

Romeine: 3de eeu: $\mathrm{P} 27,40,460220$ sa; 4de eeu: $\mathrm{P} 10 \times \mathrm{B} 02150221$ bo mf goth.

1 Korintiërs: 3de eeu: $\mathrm{P}^{15,46}$ sa; 4de eeu: $\times \mathrm{B} 01850270$ bo mf goth.

2 Korintiërs: 3de eeu: $\mathrm{P}^{46}$ sa; 4 de eeu: $X \mathrm{~B}$ bo $\mathrm{mf}$ goth.

Literatuur: CPH Bammel 1985; Ellis 1981; P Lampe 1985; Murphy 1959; Osburn 1981b; Price 1967; Thrall 1976; 1981; Zuntz 1953.

\section{(a) Rm 16: 23}

Die laaste teks in die NAB wat van 'n tekskritiese nota voorsien is, kom in die Romeinebrief by $\mathrm{Rm}$ 16: 23 voor, waarin gesê word dat die groet 'Die genade van die Here Jesus Christus sy met julle almal. Amen' (tradisioneel vers 24) weggelaat is. Die kritiese apparaat lyk soos volg:

(1) Weglating: P46,61 $\times$ A B C $811739 p c$ z vg sa bo eth Orig

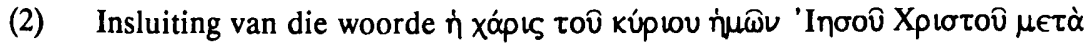

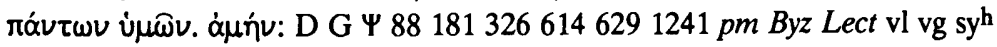
goth Chrys en enkele kerkvaders

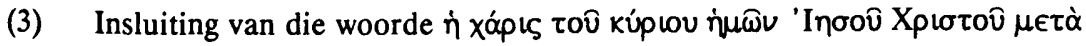

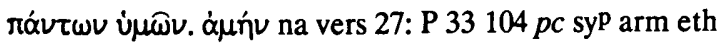

Eksterne getuienis ondersteun lesing 1, omdat dit in al die oudste en beste bronne ( $\mathrm{P} 46,61$ × A B C sa Orig) voorkom en 'n goeie vroeë geografiese verspreiding geniet. Lesing 2, daarenteen, kan andermaal na die Westerse teks teruggevoer word, terwyl lesing 3 in te min vroeë getuienis gevind word om op eksterne gronde ernstig oorweeg te word. Transkripsionele getuienis bevestig bogenoemde, aangesien dit makliker is om die ontstaan van lesings 2 en 3 as lesing 1 te verklaar. Beide lesings is waarskynlik pogings om die brief van 'n gepaste slot te voorsien, omdat dit sonder 
die normale seëngroet eindig. Die feit dat daar in vers 20 so 'n seëngroet voorkom, het waarskynlik as die bron gedien vir die ontstaan van hierdie groet. Op intrinsieke gronde is dit ewe-eens moeilik om die lang lesing as oorspronklik te aanvaar, omdat dit moeilik denkbaar is dat die brief 'n dubbele groet so kort na mekaar sou bevat. Die feit dat vers 20 reeds 'n groet bevat en dus 'n gepaste afsluiting vir die brief is, bring mee dat die res van die brief moontlik 'n latere byvoeging tot die oorspronklike brief is. Die probleem hang nou saam met die volgende, naamlik die doksologie by die slot van die Romeinebrief.

\section{(b) $\operatorname{Rm} 16: 25-27$}

Die presiese slot van die Romeinebrief is 'n probleem wat die historiese kritiek in gedrang bring. Nie alleen is daar twyfel oor die outentisiteit van die doksologie aan die einde van Romeine ( $\mathrm{Rm}$ 16: 25-27) nie, maar die presiese plek waar dit ingesluit behoort te word, is ook onseker. Dit raak naamlik die woorde '(25) God is magtig om julle te laat vasstaan ooreenkomstig die evangelie van Jesus Christus wat ek verkondig, en ooreenkomstig die openbaring van die geheimenis. Eeue lank het dit geheim gebly, (26) Maar nou is dit geopenbaar. Aan die hand van die geskrifte van die profete en in opdrag van die ewige God is dit aan alle nasies bekend gemaak sodat hulle in God kan glo en aan Hom gehoorsaam kan wees. (27) Aan Hom, die enigste en alwyse God, behoort die heerlikheid deur Jesus Christus tot in ewigheid! Amen'. Die kritiese apparaat is soos volg:

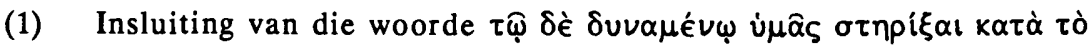

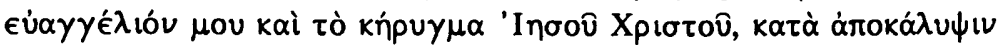

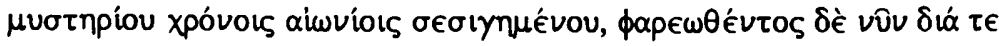

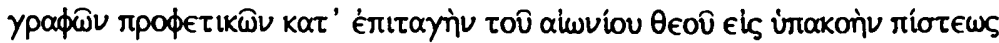

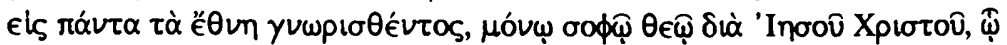

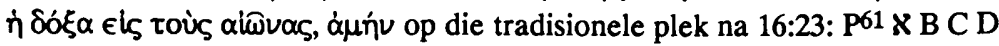
811739 vl vg syp sa bo eth $\mathrm{Cl}$ Orig

(2) Insluiting van die woorde hierbo op die tradisionele plek na 16: 23 en na 14: 23: A P 53388104 arm

(3) Insluiting van die woorde hierbo na 14: 23: L $\Psi 1813266141241$ Byz sy Chry Cyr en enkele kerkvaders

(4) Insluiting van die woorde hierbo na 15: 33: $\mathrm{p}^{46}$

(5) Weglating: F G $629 \mathrm{~g}$ goth Marc

Die eksterne getuienis ondersteun lesing 1. Dit kom in die oudste en beste bronne 
voor ( $\mathrm{P}^{61} \times \mathrm{B}$ C sa) en het ook verreweg die beste geografiese verpreiding. Al die ander lesings kom in laatgedateerde bronne of slegs enkele bronne voor, wat die moontlikheid verhoog dat dit die gevolg van die skriptor van die spesifieke bron se werk is. Die uitsondering is die weglating, wat steun van die vroeë Westerse bronne $\mathrm{g}$ en Marcion het. Die feit dat Marcion die weglating ondersteun, maak die lesing verdag, omdat dit bekend was dat Marcion'n hersiene uitgawe van die Paulusbriewe by sy kanon ingesluit het. Hierdie lesing kon weggelaat gewees het in hierdie hersieningsproses. Transkripsionele getuienis lewer geen duidelike uitspraak nie en kan slegs in 'n negatiewe sin oorweeg word. Dit is duidelik hoe lesings 1, 2, 3 en 4 ontstaan het, maar vir die byvoeging of weglating van die woorde is geen duidelike getuienis beskikbaar nie. Weens die probleme ten opsigte van die slot van die oorspronklike Romeinebrief is die doksologie telkens aan die einde van die slot wat vir die betrokke skriptors bekend was, geplaas, voordat die res van die teks (waarskynlik uit 'n later bron) bygevoeg is. So is lesing 1 waarskynlik van manuskripte gekopieer wat die hele brief, soos dit vandag bekend is, bevat het. Die archetipe van lesing 3 het waarskynlik by $R m$ 14: 23 opgehou, waar die doksologie ingevoeg is. Later is die res van die brief van 'n ander archetipe, waarin die res van die brief vervat is, gekopieer. Die doksologie is egter nie weer herhaal nie. In die geval van lesing 2 het dieselfde gebeur. Dié doksologie is egter in die kopiëring van die laaste gedeelte bygevoeg. Lesing 4 het waarskynlik op dieselfde wyse ontstaan, deurdat die aanvanklike archetipe by 15: 33 geëindig het. Dit is duidelik dat, indien aanvaar word dat die doksologie oorspronklik deel van die brief was, dit nodig is om eers te bepaal waar die oorspronklike brief geëindig het, voordat sy posisie in die brief bepaal kan word. Om op transkripsionele gronde te oordeel of die doksologie enigsins in die oorspronklike brief gestaan het of nie, is 'n moeiliker probleem, omdat daar geen duidelike rede vir die weglating of byvoeging daarvan bestaan nie. Daar kan nie sonder meer geredeneer word dat dit bygevoeg is om aan die brief ' $n$ gepaste afsluiting te gee nie, omdat dit 'n totaal ander soort afsluiting is as dié waarmee die Pauliniese briewe gewoonlik afgesluit word. Indien hierdie soort harmoniëring die rede vir die byvoeging van die betrokke gedeelte was, sou dit waarskynlik eerder ' $n$ formulering soortgelyk aan die problematiese lesing in $\mathrm{Rm} 16$ : 23 bevat het. Intrinsieke getuienis blyk met die eerste oogopslag die weglating te ondersteun, omdat 'n besonder hoë konsentraat nie-Pauliniese taal- en stylelemente daarin voorkom. Dit is seker dat hierdie drie tekste nie by die skrywe van die Romeinebrief ontstaan het nie. Aan die ander kant lyk die formulering daarvan besonder baie na 'n aanhaling uit 'n vroeë belydenis, op grond waarvan die afwykings in taal en styl verklaar kan word. Daar is ook ander voorbeelde van sulke aanhalings in die corpus Paulinum. Dit is duidelik dat hierdie variasie-eenheid 'n 
besonder komplekse tekskritiese probleem is, dat die getuienis goed gebalanseerd is en dat ' $n$ duidelike uitspraak oor die oorspronklike lesing baie moeilik is. Die rede hiervoor is dat die probleem waarskynlik nie 'n suiwer tekskritiese probleem is nie, maar met die hele outentisiteits- en interpolasievraagstuk van die Pauliniese briewe saamhang.

Literatuur. JK Elliott 1981d; Gamble 1977; Hurtado 1981a.

\section{(c) 1 Kor 13:3}

In 1 Kor 13: 3 kom 'n variasie-eenheid voor wat 'n direkte invloed op die vertaling van die gedeelte het en ook in die twee Afrikaanse vertalings gereflekteer word. Hierdie vers lui soos volg in die $\mathrm{OAB}$ : 'al sou ek my liggaam oorgee om verbrand te word', terwyl dit in die NAB soos volg lui: 'en al gee ek my liggaam prys om my daarop te kan beroem'. Die kritiese apparaat van hierdie variasie-eenheid is soos volg:

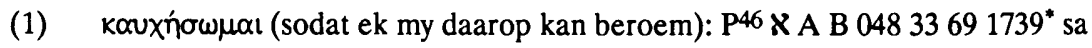
bo eth $\mathrm{Cl}$ Orig Hier en enkele kerkvaders

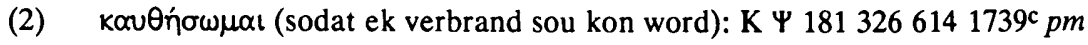
Byz Orig Chrys Cyr (vl vg goth arm eth Tert Cy en 'n aantal Latynse kerkvaders) en enkele kerkvaders

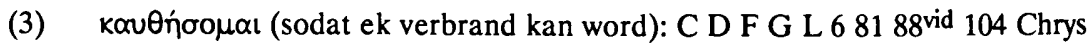
Cyr $p c$ (vl vg goth arm eth en 'n aantal Latynse kerkvaders) en enkele kerkvaders

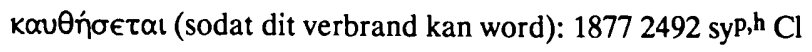

Eksterne getuienis vorm 'n interessante prentjie in hierdie variasie-eenheid. Hoewel lesing 1 in die oudste en beste bronne ( $\mathrm{P}^{46} \times \mathrm{A} \mathrm{B}$ sa) voorkom, is feitlik al hierdie bronne deel van die Alexandrynse teks en geografies dus beperk. Lesings 2 en 3 daarenteen (wat in betekenis dieselfde is, maar in grammatikale vorm verskil) is in die vroegste getuienis egter weer geografies tot die Westerse teks beperk, vanwaar dit later in die Bisantynse teks oorgeneem is. Die rede waarom 'n aantal getuienisse in hakies by beide lesings 2 en 3 genoteer is, is omdat die verskil tussen die twee lesings 'n grammatikale kwessie eie aan die Griekse taal raak, waarvoor daar geen ekwivalent in Latyn en die ander tale wat genoem word, bestaan nie. Lesing 4 is op eksterne gronde moeilik as oorspronklik te beskou, omdat dit in slegs enkele bronne voorkom. Hoewel geografiese oorwegings dus geen rol in hierdie probleem speel 
nie, is die feit dat die beste bronne lesing 1 ondersteun, 'n aanduiding dat lesing 1 hier die oorspronklike lesing mag wees. Transkripsionele getuienis blyk die eksterne getuienis te ondersteun, omdat lesing 1 duidelik die moeilike lesing is, en dit meer waarskynlik is dat een van lesings 2,3 of 4 by lesing 1 sou ontstaan het as dat lesing 1 sou ontstaan het indien een van die ander oorspronklik was. Die probleem is naamlik dat indien 'die liggaam oorgegee word, sodat ek my daarop kan beroem' (lesing 1), daar niks is waartoe die liggaam oorgegee word nie. Dit lyk dus of die sin iets kort om dit te voltooi. 'n Skriptor het waarskynlik gedink dat daar ' $n$ fout in sy archetipe was en dit verander na 'die liggaam oorgegee word, om verbrand te word' (lesing 2) in 'n poging om die passasie af te rond. In Grieks behels hierdie verandering slegs een letter: 'n $X$, wat na 'n $\theta$ verander moet word: KAY $\underline{X} H \Sigma \Omega M A I$ en KAY $\underline{\theta} H \Sigma \Omega M A I$. Die grammatikale probleem wat hierdie konstruksie meegebring het ( $\mathrm{k} \propto \cup \theta \dot{n} \sigma \omega \mu \alpha \mathrm{t}$ is 'n futurum subjunktief of konjunktief 'n vorm wat nie in Grieks bestaan nie), het tot korreksie gelei, sodat lesing 3 ontstaan het. Die futurum subjunktief is verander na 'n futurum indikatief. Weer

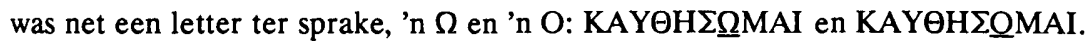
Uiteindelik het 'n sintaksisprobleem lesing 4 tot gevolg gehad. Die gebruik van die eerste persoon in die frase 'die liggaam oorgee, sodat $e k$ verbrand kan word' is problematies. Dit is gevolglik in lesing 4 na die 3 de persoon verander: 'die liggaam oorgee, sodat dit verbrand kan word '.

Literatuur: JK Elliott 1971b; Petzer 1989a.

\subsection{Die kort Briewe}

Die oudste bronne van die kort Pauliniese Briewe is die volgende:

Galasiërs: 3de eeu: $\mathrm{P} 46,51$ sa; 4de eeu: $\times \mathrm{B} 0176$ ac bo mf goth.

Efesiërs: 3de eeu: $\mathrm{P}^{49}$ sa; 4de eeu: $\times \mathrm{B} 0230$ bo $\mathrm{mf}$ goth.

Filippense: 3de eeu: $\mathrm{P}^{16,46} \mathrm{sa}$; 4 de eeu: $\mathrm{X} \mathrm{B}$ bo $\mathrm{mf}$ goth.

Kolossense: 3de eeu: $\mathrm{P}^{46}$ sa; 4de eeu: $\mathrm{X}$ B 0207 bo $\mathrm{mf}$ goth.

1 Tessalonisense: $3 \mathrm{de}$ eeu: $\mathrm{P} 30,46,65 \mathrm{sa}$; $4 \mathrm{de}$ eeu: $\mathrm{K} \mathrm{B}$ bo $\mathrm{mf}$ goth.

2 Tessalonisense: $3 \mathrm{de}$ eeu: sa; $4 \mathrm{de}$ eeu: $\mathrm{X} \mathrm{B}$ bo $\mathrm{mf}$ goth.

Filemon: 3de eeu: $\mathrm{P}^{87}$ sa; $4 \mathrm{de}$ eeu: $\mathrm{X}$ bo $\mathrm{mf}$ goth.

Literatuur. Baarda 1985; 1988a; Best 1979; Collins 1984; Eshbaugh 1979; Kilpatrick 1983b; Lash 1976; Moir 1976; Van Rensburg 1986. 
(a) Ef 3: 14

In Ef 3: 14 kom 'n tekskritiese probleem voor wat 'n invloed op die twee Afrikaanse vertalings gehad het. Volgens die OAB kniel Paulus naamlik 'voor die Vader van onse Here Jesus Christus', terwyl hy in die NAB slegs 'voor die Vader' kniel. Die kritiese apparaat vir hierdie probleem is soos volg:

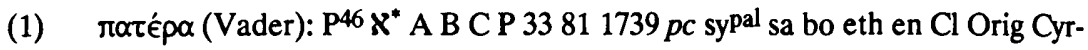
Jer Hier en enkele kerkvaders

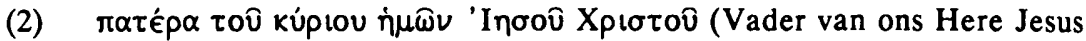
Christus): Kc D G K $\Psi 8810418132661412412495$ pm Byz Lect vl vg syp,h goth arm Orig Chrys en 'n hele aantal kerkvaders

In hierdie variasie-eenheid kom daar andermaal iets van 'n tweedeling in die eksterne getuienis voor. Waar lesing 1 in die oudste en beste bronne ( $\mathrm{P}^{46} \times \mathrm{A}$ B C sa) voorkom, is die vroegste getuienis tot die Alexandrynse teks beperk. Die vroegste getuienis van lesing 2 is egter weer tot die Westerse teks beperk, vanwaar dit na ander tekstipes oorgegaan het. Op grond van die waarde van die getuienis sal lesing 1 egter op eksterne gronde as waarskynlik die oorspronklike gekies word. Transkripsionele getuienis bevestig hierdie keuse. Terwyl daar geen rede vir die weglating van die frase is nie, kom die byvoeging daarvan ooreen met die neiging onder skriptors om die naam van God en van Jesus uit te brei. As sodanig is dit ook 'n tipiese Westerse interpolasie.

\section{(b) Ef 5: 9}

Volgens die OAB lees Ef 5: 9 soos volg: 'Want die vrug van die Gees bestaan in alle goedheid'. Wanneer dit met die NAB vergelyk word, is dit duidelik dat variasie op die betrokke plek in die bronne voorkom: 'Uit die lig kom alles voort wat goed is'. Die kritiese apparaat by hierdie gedeelte is soos volg:

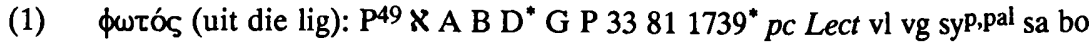
goth arm eth Orig Hier en enkele kerkvaders

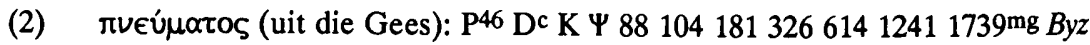
sy ${ }^{\text {b }}$ Chrys en enkele kerkvaders

Met die uitsondering van $\mathrm{P}^{46}$ kom lesing 1 in al die oudste en beste manuskripte voor. Lesing 1 het ook 'n wye geografiese verspreiding, veral omdat dit in die vroegste bronne van sowel die Alexandrynse as Westerse tekste voorkom. Hoewel 
lesing 2 vroeë getuienis in veral $P^{46}$ het, is die beperktheid van die vroeë getuienis van hierdie lesing, wanneer dit met die uitgebreidheid van lesing 1 se vroegste getuienis vergelyk word, 'n probleem wat getuig teen die aanspraak van hierdie lesing om die oorspronklike te wees. Eksterne getuienis ondersteun lesing 1 dus baie duidelik. Transkripsionele getuienis is met die eerste oogopslag ietwat verdeeld. By nadere ondersoek blyk dit egter lesing 1 te ondersteun. Die ontstaan van lesing 1 , фwtós, (van die lig) kan gesien word as die gevolg van harmoniëring met die konteks, omdat $\phi \omega ́ s$ (lig) twee keer in die direk voorafgaande vers voorkom. Dit is

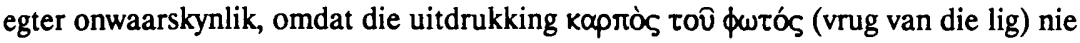
'n bekende uitdrukking vir skriptors sou wees nie. Die harmoniëring sou verder ietwat geforseerd wees, omdat фús (lig) in die variasie-eenheid in 'n effens ander

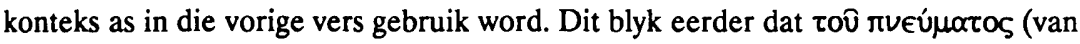
die Gees) (lesing 2) aan die hand van harmoniëring met die bekende uitdrukking

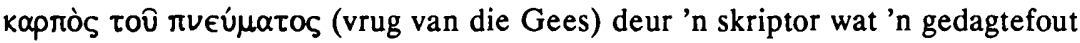
gemaak het, ontstaan het. Dit is natuurliker om laasgenoemde neer te skryf as eersgenoemde, wanneer iemand konsentrasie verloor. Op grond hiervan sal lesing 1 dus as die oorspronklike gekies word.

\section{(c) 1 Ts $1: 1$}

Die eerste brief aan die Tessalonisense begin in onsekerheid. Dit is onduidelik of die Brief met 'n kort groetwoord 'Genade en vrede vir julle' (NAB) of 'n lang en uitgebreide groetwoord 'Genade vir julle en vrede van God onse Vader en die Here Jesus Christus' (OAB) begin. Die kritiese apparaat is soos volg:

(1) Eipńm (vrede): B G $\Psi 1739 p c$ vl vg syp,pal(mss) sa mf arm eth Orig Chrys en enkele kerkvaders

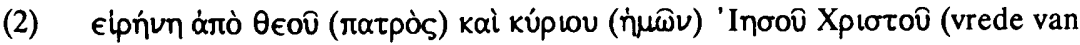
God en die Here Jesus Christus): D $p c \mathrm{~d}$ e bomss eth Chrys en enkele kerkvaders

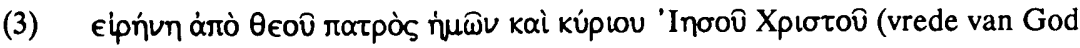
en die Here Jesus Christus): X A I K P 3381881041813266141241 Byz Lect syh,pal(ms)

Die eksterne getuienis is verdeel tussen veral lesings 1 en 3 . Waar lesing 1 sommige van die oudste en beste manuskripte (B sa) en manuskripte van 'n redelike verspreiding (Alexandryns en Westers - vl) ter ondersteuning het, het lesing 3 ook sommige van die oudste en beste manuskripte $(\mathrm{X} A)$ tot sy ondersteuning. Dit het 
ewe-eens 'n redelike vroeë geografiese verspreiding, ofskoon nie so goed soos lesing 1 nie. Lesing 2 blyk ' $n$ tipiese Westerse lesing te wees, ofskoon die feit dat dit so naby aan lesing 3 se bewoording is, meebring dat die bronne waarin dit voorkom, saam met dié van lesing 3 as verdere steun vir die bestaan van die lang lesing geneem mag word. Dit bring die geografiese verspreiding van lesing 3 (saam met 2) dus op dieselfde peil as dié van lesing 1. Eksterne getuienis gee dus nie werklik uitspraak nie. Ten opsigte van transkripsionele getuienis is die saak feitlik ewe problematies en ook in hierdie opsig is daar geen duidelike getuienis nie. Terwyl daar geen duidelike rede is waarom die betrokke frase weggelaat sou word indien dit oorspronklik is nie, is daar 'n moontlike verklaring vir die byvoeging daarvan, naamlik die feit dat dit by die neiging onder skriptors om frases af te rond, pas.

\subsection{Die Pastorale Briewe}

Die oudste bronne van die Pastorale Briewe is die volgende:

1 Timoteus: 3de eeu: sa; $4 \mathrm{de}$ eeu: $\mathrm{K}$ bo $\mathrm{mf}$ goth.

2 Timoteus: 3de eeu: sa; $4 \mathrm{de}$ eeu: $\boldsymbol{X}$ bo $\mathrm{mf}$ goth.

Titus: 3de eeu: $\mathrm{P}^{32}$ sa; 4de eeu: $\mathrm{X}$ bo $\mathrm{mf}$ goth.

Litcratuur: Elliott 1968a; 1968b; Junack 1976.

\section{(a) $1 \operatorname{Tm} 3: 16$}

Die vertaling van die bekende lied in $1 \mathrm{Tm}$ 3: 16 verskil in die twee Afrikaanse vertalings. Terwyl die $\mathrm{OAB}$ vers $16 \mathrm{~b}$ weergee met die woorde: 'God is geopenbaar in die vlees', gee die NAB dit weer met die woorde 'As Mens het Jesus in die wêreld gekom'. Die onderliggende rede vir die verskil lê in hierdie geval in sowel die verandering in grondteks as die verandering in vertaalmetode. Terwyl die OAB die ou grondteks letterlik weergee, gee die NAB 'n geïnterpreteerde weergawe van die nuwe grondteks (wat andersins feitlik onvertaalbaar is). Die kritiese apparaat en letterlike vertaling van die lesings is soos volg:

(1) ös (Hy wat - NAB): $\mathrm{K}^{*} \mathrm{~A}^{*} \mathrm{C}^{*} \mathrm{G} 33 p c$ syh(mg),pal goth eth (syp,h sa bo arm eth Efraim) Orig Hier Cyr en enkele kerkvaders

(2) ö (dit wat): $D^{*} \mathrm{vl} \mathrm{vg} \mathrm{(syp,h} \mathrm{sa} \mathrm{bo} \mathrm{arm} \mathrm{eth} \mathrm{Efraim)} \mathrm{enkele} \mathrm{kerkvaders}$

(3) $\quad \omega(\mathrm{o} !): 061$

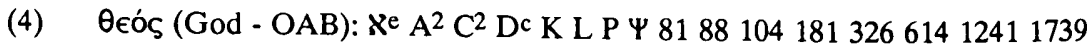


2495 pm Byz Lect Did Chrys en enkele kerkvaders

Hoewel daar vier variante lesings in hierdie variasie-eenheid voorkom, is slegs lesings 1 en 4 werklik ter sake. Lesing 3 kan reeds op eksterne gronde uitgeskakel word, omdat dit slegs in een manuskrip voorkom, en waarskynlik'n verandering (of fout) van die skriptor van die betrokke manuskrip was. Lesing 2, daarenteen, kom, met die moontlike uitsondering van die bronne tussen hakies, slegs in Westerse bronne voor en het waarskynlik in 'n vroeë archetipe van hierdie teks ontstaan. Dit laat lesings 1 (hy wat - die betreklike voornaamwoord) en 4 (God). Dit is duidelik dat lesing 1 (die betreklike voornaamwoord) die oudste en beste bronne $\left(\boldsymbol{X}^{*} \mathrm{~A}^{*} \mathrm{C}^{*}\right.$ sa) ter ondersteuning het en ook 'n wye geografiese verspreiding geniet. Dit kom in 'n groot verskeidenheid bronne voor, veral as in ag geneem word dat lesing 2 , waarskynlik uit lesing 1 ontstaan het en dus indirekte getuienis vir die bestaan van lesing 1 bied. Lesing 4 kom daarenteen feitlik uitsluitlik in Bisantynse bronne voor. Eksterne getuienis ondersteun dus lesing 1. Op sigself is transkripsionele getuienis moeilik interpreteerbaar. Indien lesing 4 as die oorspronklike geneem word, moet aanvaar word dat lesing 1 as gevolg van letterverwarring ontstaan het. Omdat die nomen sacrum van $\theta \epsilon o ́$, (God) met die uitsondering van twee strepies, presies soos die betreklike voornaamwoord lyk: $\overline{\theta \Sigma}$ en $O \Sigma$, kon 'n skriptor, wat van 'n archetipe gekopieer het waarvan die strepie van die $\overline{\boldsymbol{\theta}}$ en die strepie van die nomen sacrum onduidelik was, dit maklik vir die betreklike voornaamwoord aangesien het en dit so in sy manuskrip oorgeskryf het. Die probleem hiermee is egter dat dit moeilik verklaar kan word hoe so 'n fout so vroeg in die geskiedenis soveel onafhanklike steun kon verwerf, terwyl die korrekte lesing teen die 4 de eeu skielik weer sy opwagting maak. Op sigself lyk hierdie verklaring moontlik. Teen die agtergrond van die teksgeskiedenis is dit egter onwaarskynlik. Die verandering van ös na $\theta \in o ́ s$ is in die lig van die dokumentêre geskiedenis veel makliker verklaarbaar. Dit pas naamlik baie mooi in die algemene tendense van die Bisantynse teks om frases af te rond deur die betekenis van 'n bepaalde gedeelte meer eksplisiet te maak. So is dit wat implisiet in die gedeelte is, eksplisiet gemaak deur die betreklike voornaamwoord (hy wat) in die nomen sacrum van die woord waarna dit verwys, $\overline{\Theta \Sigma}$ (God) te verander.

\section{(b) $1 \operatorname{Tm} 4: 10$}

In $1 \mathrm{Tm}$ 4: 10 lees die OAB: 'want hiervoor ... word ons gesmaad', terwyl die NAB die woorde 'met hierdie vooruitsig ... stry ons' bevat. Die kritiese apparaat vir hierdie twee lesings is soos volg: 


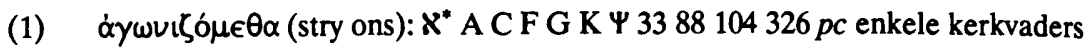

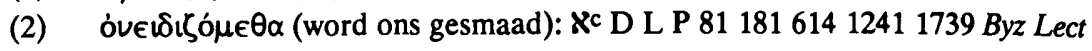
vl vg syp,h sa bo goth arm eth Orig Chrys en enkele kerkvaders

Terwyl lesing 1 die oudste en beste manuskripte $\left(\boldsymbol{X}^{*} \mathrm{~A} C\right)$ ter ondersteuning het, is dit geografies tot die Alexandrynse teks beperk. Lesing 2, daarenteen, se vroegste steun is geografies beter versprei, deurdat dit in veral die Westerse teks voorkom, maar ook in vroeë Alexandrynse bronne soos die Sahidiese en Bohairiese vertalings. Eksterne getuienis is dus verdeel, hoewel die feit dat die beste Griekse manuskripte lesing 1 ondersteun, moontlik effens meer gewig mag dra as die geografiese verpreiding. Transkripsionele getuienis lewer ewe-eens geen duidelike beslissing nie. Terwyl lesing 1 deur middel van 'n konsentrasiefout onder invloed van die gedagte van stryd

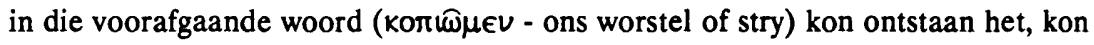
lesing 2 ontstaan het onder invloed van die vervolginge in die vroeë kerk, in 'n poging om die onmiddellike herhaling van dieselfde gedagte (stryd) te vermy. Op grond van intrinsieke getuienis kan moontlik uit die konteks afgelei word dat lesing 1 eerder die oorspronklike was, omdat die gedagte van smaad nie in die konteks aanwesig is nie en sulke herhaling van gedagtes nie onbekend of onnatuurlik in die Nuwe Testament is nie.

\subsection{Hebreërs}

Die oudste bronne van die Hebreërbrief is die volgende:

3de eeu: P12,13,46 sa; 4de eeu: $\mathrm{P}^{17} \times \mathrm{B} 0228$ bo mf goth.

Literatuur: Frede 1987; Kilpatrick 1941a; Wolmarans 1984.

\section{(a) Hb 9: 11}

Tree Jesus volgens Hb 9: 11 op as die hoëpriester 'van die weldade wat nou verwesenlik is' (NAB) of 'van die toekomende weldade' (OAB)? Die tekskritiese apparaat by hierdie probleem is soos volg:

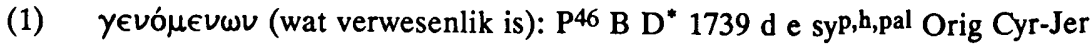
Chrys

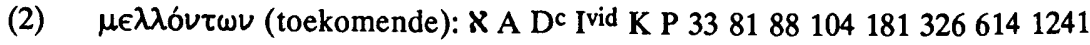
2495 Byz Lect vl vg syh(mg) sa bo mf arm eth Eus Efraim Cyr-Jer Chrys Cyr en talle kerkvaders 
Eksterne getuienis is verdeeld in hierdie tekskritiese probleem. Albei lesings kom in sommige van die oudste en beste manuskripte voor, lesing 1 in $\mathrm{P}^{46}$ en B, en lesing 2 in $\mathrm{X}$ A en sa, terwyl albei in bronne van die vroeë tekstipes voorkom. Dit is onmoontlik om enige uitspraak ten opsigte van die oorspronklikheid van enige van die twee lesings op hierdie gegewens te baseer. Op transkripsionele gronde is die ontstaan van lesing 2 makliker as dié van lesing 1 verklaarbaar, aangesien dit uit harmoniëring aan $\mathrm{Hb}$ 10: 1 kon ontstaan het. Daar is geen ooglopende rede waarom 'n skriptor lesing 2 na lesing 1 sou verander het indien lesing 2 die oorspronklike was nie.

\section{DIE ALGEMENE BRIEWE}

Soos die teks van die Pauliniese Briewe is daar oor die teks van die Algemene Briewe min gedoen. By die Institut für neutestamentliche Textforschung in Münster, Wes-Duitsland, word daar onder leiding van Barbara Aland egter op navorsing oor hierdie deel van die Nuwe Testament gekonsentreer in 'n poging om 'n kritiese teks met 'n volledige apparaat te produseer.

Geen noemenswaardige teks van hierdie briewe het verskyn nie. Die eerste resultate van die projek van die Institut für neutestamentliche Textforschung het egter onlangs verskyn. Daarin is uitgawes van die papiri, die Siriese teks en die Koptiese teks van die Algemene Briewe gepubliseer. Ook van die Algemene Briewe het die oud-Latynse teks in die Vetus Latina-reeks van Beuron, saamgestel deur Walter Thiele, verskyn.

Literatuur: B Aland 1986b; K Aland 1969/70; 1970/71; 1987a; 1987b; 1987c; 1987d; Carder 1969/70; Duplacy 1969/70; Gallaghar 1970; Kilpatrick 1944b; 1980; Richards 1974; 1975; 1976; Thiele (ed) 19561969.

\subsection{Die Jakobusbrief}

Die oudste bronne van die Jakobusbrief is die volgende:

3de eeu: $\mathrm{P}^{20,23}$ sa; 4de eeu: $\mathrm{X} B$ ac bo $\mathrm{mf}$.

Literatuur. Hodges 1963. 


\subsection{Die Petrusbriewe}

Die oudste bronne van die twee Petrusbriewe is die volgende:

1 Petrus: 3de eeu: P72,81 sa; 4de eeu: $\times$ B 0206 bo mf.

2 Petrus: 3de eeu: $P^{72}$ sa; 4 de eeu: $X$ B bo $\mathrm{mf}$.

Literatuur. Beare 1961; Jordaan 1988; Rodgers 1981; Thiele 1965a.

\section{(a) 2Pt 3: 10}

In 2 Pt 3: 10 kom 'n verandering in die grondtekste van die $O A B$ en $N A B$ voor, wat nie duidelik in die vertaling daarvan weerspieël word nie. Beide vertalings lees in hierdie vers dat die aarde en alles daarop 'sal verbrand'. Die enigste aanduiding van 'n ander grondteks in die NAB is die byvoeging 'en smelt'. Die rede waarom die $\mathrm{NAB}$ net hierdie klein verskil het, terwyl dit op 'n totaal ander grondteks gebaseer is, is waarskynlik omdat die die grondteks baie moeilik vertaalbaar is. Reeds in die vroegste oorlewering van hierdie teks, was daar al probleme mee. Die apparaat lyk soos volg:

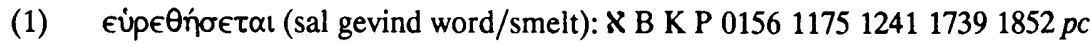
syph,h(mg) arm Orig

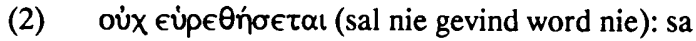

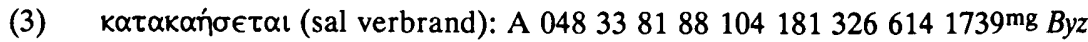
Lect $\mathrm{vl}$ vg syh bo eth enkele kerkvaders

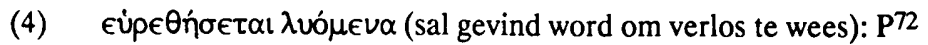

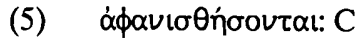

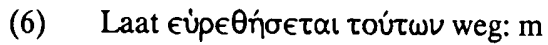

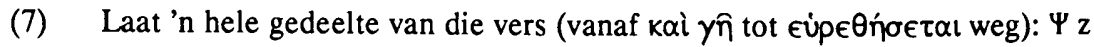
en enkele kerkvaders

Op grond van eksterne getuienis is daar net twee lesings wat werklik aanspraak kan maak om oorspronklik te wees, naamlik lesings 1 en 3, omdat al die ander in slegs enkele dokumente voorkom en dus aan die skriptors van die betrokke manuskripte toegeskryf kan word, selfs al is sommige van hierdie manuskripte ou en belangrike bronne (die Sahidiese vertaling in die geval van lesing 2 en $\mathrm{P}^{74}$ in die geval van lesing 4). Dit laat lesings 1 en 3, en op grond van sowel die ouderdom as die kwaliteit en geografiese verspreiding moet lesing 1 voorkeur bo lesing $3 \mathrm{kry}$. Met die uitsondering van A kom lesing 3 slegs voor in Westerse bronne en later in bronne 
wat aan die Westerse teks verwant is, terwyl lesing 1 in 'n verskeidenheid bronne voorkom. Wanneer die transkripsionele getuienis oorweeg word, word dit duidelik dat lesing 1 waarskynlik die oorspronklike was en dat die ander lesings ontstaan het uit 'n poging om die interpretasieprobleem van lesing 1 die hoof te bied. Dit is duidelik dat lesing 1 baie moeilik interpreteerbaar is. Wat sou dit beteken dat die aarde en alles daarop 'gevind' word, in 'n konteks waarin daar van die vernietiging van alles op 'die dag van Here' gepraat word? Baie duidelik het lesing 2 probeer om hierdie probleem op te los deur dit so te verander dat die aarde en alles daarop nie gevind sal word nie. Lesing 3 het die probleem probeer oplos deur die gedeelte met die konteks te harmonieer en die voorafgaande gedagte ( $\lambda \cup \theta$ ń $\sigma \in \tau \alpha l$ - losgemaak) daarby in te sluit. Lesings 6 en 7 het die saak probeer beredder deur die problematiese gedeeltes weg te laat, terwyl lesings 3 en 5 die saak probeer oplos het deur die woord met ander te vervang; lesing 3 waarskynlik ook na aanleiding van die voorafgaande gedagte, waar dieselfde woord voorkom. Dit is duidelik dat daar baie sterk transkripsionele getuienis is wat die eerste lesing hierbo steun. Oor wat die woord binne die konteks beteken, kan nie hier uitsluitsel gegee word nie. Waarskynlik is dit iets soos in die NAB weergegee word, naamlik dat die aarde en alles daarop deur 'n louteringsproses vernuwe sal word.

\subsection{Die Johannesbriewe}

Die oudste bronne van die drie Johannesbriewe is die volgende:

1 Johannes: 3de eeu: $\mathrm{P}^{9}$ sa; 4 de eeu: $\mathrm{X} \mathrm{B}$ bo $\mathrm{mf}$.

2 Johannes: 3de eeu: sa; 4 de eeu: $\mathrm{X}$ B bo $\mathrm{mf}$.

3 Johannes: 3de eeu: sa; 4 de eeu: $\mathrm{X}$ B bo mf.

Literatuur: Ehrman 1988b; Richards 1977a.

\section{(a) $1 \mathrm{Jh} 5: 7-8$}

Daar is reeds talle kere in die boek na die comma johanneum verwys. Dit raak naamlik die weglating in die NAB van die enigste eksplisiete verwysing na die Drieeenheid, wat in die OAB as $1 \mathrm{Jh}$ 5: 7-8 voorkom: 'in die hemel, die Vader, die Woord en die Heilige Gees, en hierdie drie is een; en daar is drie wat getuig op die aarde'. Die kritiese apparaat van hierdie gedeelte is soos volg: 
ar syp, h sa bo arm eth baie kerkvaders

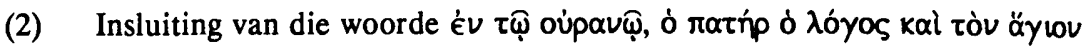

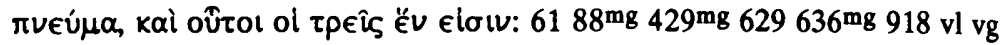
enkele kerkvaders

Eksterne getuienis spreek in hierdie variasie-eenheid feitlik vanself. Met die uitsondering van ses Middeleeuse Griekse manuskripte kom die betwiste woorde (lesing 2) in geen enkele Griekse bron voor nie. Al vroeë getuienis wat dit het, is die Vetus Latina. Dit is duidelik dat lesing 1 in al die vroegste en beste bronne voorkom en 'n baie wye geografiese verspreiding geniet. Ook op transkripsionele gronde ondersteun die getuienis lesing 1 , omdat lesing 2 na 'n tipiese Westerse interpolasie lyk. Dit is waarskynlik uit die een of ander vroeë kerklike formule deur ortodokse skriptors ingevoeg, omdat daar geen eksplisiete verwysing na die Drie-eenheid in die Bybel voorkom nie. Die verwysing na die drie aardse getuies in vers 8 bied die ideale konteks vir so 'n verwysing na die Drie-eenheid.

Literatuur. De Jonge 1980a.

\subsection{Die Judasbrief}

Die oudste bronne van die Judasbrief is die volgende:

3de eeu: $\mathrm{P}^{72,78}$ sa; 4de eeu: $\mathrm{X} B$ bo $\mathrm{mf}$.

Literatuur. Kubo 1976; 1981; Osburn 1981a; Wikgren 1967.

\section{(a) Jd 1}

In die openingswoorde van die Judasbrief is dit onseker of die brief gerig is aan die wat deur God 'geheilig' is (OAB) of die wat Hy 'liefhet' (NAB). Die kritiese apparaat is soos volg:

(1) ウ̇yarnuévors (aan die geliefdes): P72 X A B $\Psi 8188326^{\mathrm{mg}} 124117392495$ $p c \mathrm{vl} \mathrm{vg} \mathrm{syp,ph}$ sa bo arm eth Orig Luc en enkele kerkvaders

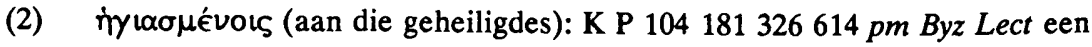
kerkvader

Dit is baie duidelik dat eksterne getuienis lesing 1 ondersteun, omdat dit in al die oudste en beste bronne ( $\mathrm{P}^{72} \times \mathrm{A}$ B sa) voorkom, asook 'n baie wye vroeë geogra- 
fiese verspreiding geniet, deurdat dit veral in die Alexandrynse en Westerse tekste voorkom. Lesing 2, daarenteen, kom slegs in bronne van die Bisantynse tekstipe voor. Ook transkripsionele getuienis ondersteun lesing 1 , omdat daar geen ooglopende rede is waarom iemand lesing 1 na lesing 2 sou verander nie, terwyl lesing 2 waarskynlik harmoniëring met 1 Kor $1: 2$ is.

\section{DIE APOKALIPS}

Die geskiedenis van die teks van die Apokalips het heeltemal anders verloop as dié van die ander boeke van die Griekse Nuwe Testament. Daar is naamlik geen duidelik identifiseerbare Westerse teks van hierdie boek nie, en ook die bestaan van 'n eenduidige meerderheids- of Bisantynse teks is problematies. Die groot groep latere manuskripte verdeel in Openbaring in duideliker subgroepe as in die ander boeke van die Nuwe Testament. Die rede vir die afwyking in die geskiedenis van hierdie boek van die normale patroon word gewoonlik in die kanongeskiedenis van die boek gesoek. Die feit dat daar so lank onsekerheid oor die posisie van die boek tussen die ander boeke van die Nuwe Testament bestaan het, word dikwels vir hierdie toestand verantwoordelik gehou. Dit maak egter 'n belangrike beginsel in die NuweTestamentiese Tekskritiek, wat ongelukkig meer in teorie as in praktyk erken word, duidelik, naamlik dat die algemene beskrywing van die teksgeskiedenis sowel vir elke corpus boeke indiwidueel as vir elke boek indiwidueel, aangepas en verfyn moet word.

Onder die merkwaardigste teksuitgawes van Openbaring is die uitgawe van $H C$ Hoskier, waarin 'n uiters volledige en akkurate kritiese apparaat van hierdie boek verskyn. Die teks van Openbaring in die GNTMT, saamgestel deur Hodges, verdien ook vermeld te word. Naas Jh 7: 53-8: 11 is dit die enigste deel van die betrokke teks wat nie bloot op die numeriese meerderheid manuskripte berus nie. Hodges het dit naamlik op grond van 'n genealogiese model, gebaseer op die meerderheidsteks, saamgestel. Hoewel die teks vanweë die uitgangspunt daarvan problematies is en waarskynlik nie 'n getroue weergawe van die oorspronklike teks is nie, is dit tog 'n merkwaardige teks. Naas hierdie twee tekste is die studie van Josef Schmid oor die teks van die Apokalips, wat vandag steeds as die standaard aanvaar word, vermeldenswaardig. Die oudste bronne van Openbaring is die volgende:

3de eeu: $\mathrm{P}^{47}$ sa; 4 de eeu: $\mathrm{P}^{18,24,85} \times 0169$ bo.

Literatuur: Hodges 1961; 1962; Hodges \& Farstad (eds) 1982; Hoskier 1929; Kilpatrick 1959; Ross 1976a; Schmid 1955-56; 1961. 


\section{(a) Opb 1: 8}

In Opb 1: 8 ontbreek die verklaring van die simbole alfa en omega in sommige bronne. In die OAB lees die teks soos volg: 'Ek is die Alfa en die Omega, die begin en die einde, sê die Here', terwyl dit in die NAB bloot 'Ek is die Alfa en die Omega' sê die Here' lees. Die apparaat van hierdie teks is soos volg:

(1) Weglating: Xa A C P 046941006161120532138 pc b syp,ph arm eth enkele kerkvaders

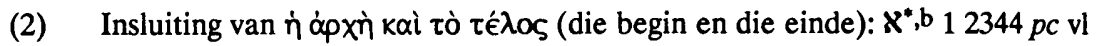
vg bo Orig Andr

Terwyl lesing 1 met die uitsondering van $\boldsymbol{X}$ in al die oudste en beste manuskripte van Openbaring (A C 2053) voorkom en 'n redelike goeie vroeë verspreiding geniet, blyk lesing 2 aanvanklik tot die oud-Latynse bronne en bronne wat deur hierdie manuskripte en hul grondteks beïnvloed kon wees, beperk te wees. Daarom sal eksterne getuienis as ondersteuning van lesing 1 beskou word. Transkripsionele getuienis blyk ietwat verdeel te wees, omdat redes vir sowel die weglating as byvoeging van die betrokke frase gevind kan word. Die frase kon weggelaat gewees het omdat skriptors gemeen het dat dit onnodig was om die betekenis van die A en $\Omega$ te herhaal. Veel eerder is dit egter om presies die teenoorgestelde rede bygevoeg, naamlik om die betekenis van die twee Griekse letters te verklaar. As sodanig kom dit ooreen met die tendens onder skriptors om die betekenis van die teks meer eksplisiet te maak.

\section{(b) Opb 5: 1}

Was die boek wat Johannes in Opb 5: 1 beskryf 'van binne en van buite' (OAB) of 'aan die voor- en aan die agterkant' (NAB) vol geskryf? Die kritiese apparaat by hierdie interessante variasie-eenheid is soos volg:

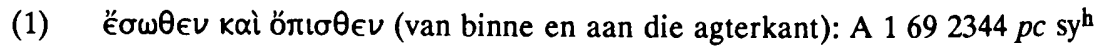
Orig Cy en enkele kerkvaders

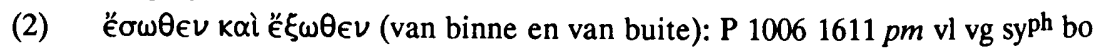
arm eth Orig Andr en enkele kerkvaders

(3)

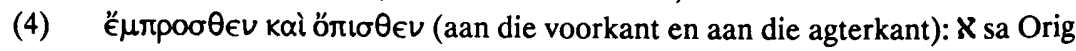

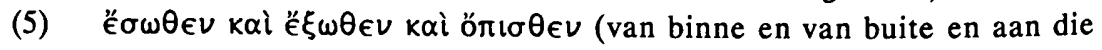
agterkant): Andr 


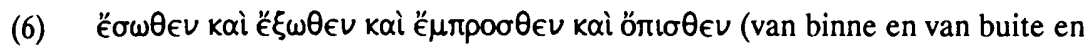
aan die voor- en aan die agterkant): 2073

Eksterne getuienis is totaal verdeel in hierdie variasie-eenheid, deurdat verskillende lesings in die oudste en beste manuskripte voorkom. Op grond van eksterne getuienis kan slegs lesings 3 en 6 met redelike sekerheid uitgeskakel word, omdat beide in slegs 'n enkele minuskel voorkom. Hoewel lesing 5 op grond van die feit dat dit slegs in een kerkvader voorkom, ook verdag lyk, is Andreas so 'n belangrike getuie van die Openbaringteks, dat dit nie sonder meer gedoen kan word nie. Sover dit die res aangaan, lewer eksterne getuienis bitter min vaste getuienis. Wanneer die saak transkripsioneel benader word, word dit effens makliker om 'n geskiedenis van hierdie variasie-eenheid daar te stel. Lesing 1 is waarskynlik die oorspronklike en al die ander lesings het ontstaan in 'n poging om die twee bywoorde op die een of ander wyse in direkte teenoorgesteldes weer te gee. So het lesing 2 ontstaan in 'n poging om vir ě $\sigma \omega \theta \in \nu$ (van binne) 'n direkte teenoorgestelde ě $\xi \omega \theta \in \nu$ (van buite) te bied. Lesing 3 het waarskynlik as gevolg van slordige kopieerwerk uit lesing 2 ontstaan, daar dit slegs die woordorde omruil. Lesing 4 het van ö agterkant) uitgegaan en probeer om ě $\sigma \omega \theta \epsilon \nu$ (van binne) met 'n direkte teenoorgestelde vir örı $\sigma \theta \in \nu$ in $̌ \mu r p o \sigma \theta \in v$ (aan die voorkant) te vervang. Lesing 5 is waarskynlik 'n poging om die probleem te vermy deur lesings 1 en 2 saam te voeg (konflasie), terwyl lesing 6 waarskynlik 'n samevoeging van lesings 1, 2, 3 en 4 probeer daarstel. Op grond van hierdie rekonstruksie is dit dus duidelik dat lesing 1 waarskynlik in die oorspronklike teks gestaan het. 